\title{
Regional Development owing to the Commodification of Rural Spaces in Japan
}

\section{TABAYASHI Akira}

Geoenvironmental Sciences, Graduate School of Life and Environmental Sciences, University of Tsukuba; Tsukuba 305-8572, Japan.
E-mail: akira@geoenv.tsukuba.ac.jp

Received August 7, 2009; Accepted December 4, 2009

Abstract This paper analyzes the possibility of regional development through the commodification of rural spaces by comparison of the Nasu region of Tochigi prefecture, the Joetsu region of Niigata prefecture, and the Kurobe alluvial fan of Toyama prefecture. In the Nasu region, individual tourism areas including Shiobara hot springs, Nasu Highland and the Nasu alluvial fan will be consolidated, and a broad based and multiple tourism area spreading dimensionally will be formed, and the possibility for the tourism area to contribute to the development of the entire Nasu region is very high owing to the commodification of rural spaces. The current issues in the Joetsu region are how to mutually connect various and small scale scattered tourism resources, what new tourism resources should be promoted, and how the viewpoints of studies and experience of tourisms should be introduced in order to create new tourism resources. Thus, the commodification of rural and urban spaces is essential. Compared to the above two mentioned regions, the Kurobe alluvial fan is a rural area with few famous tourism resources. Tourism development owing to rural commodification is limited here. Residents should evaluate familiar production activities, industries, landscape, lifestyle, and annual events and consider the direction for regional construction themselves through study and experience. The result will attract tourists from other regions and contribute to tourism development. The most significant factors of the differences among the three regions are the scale of the current and potential tourism resources and the difference in distances from major metropolitan areas.

Key words commodification, Japan, regional development, rural space, tourism

\section{Introduction}

Agriculture in Japan has declined sharply since the 1990s and various agricultural problems became obvious-for example, environmental issues caused by agriculture, a shortage of agriculture successors, strengthened rice production adjustment, competition from imported agricultural commodities, low food selfsufficiency, and a weakened rural community (Tabayashi 2007). A major shift was made from the conventional standardized agriculture which pursues mass production and efficiency to one emphasizing small volume and many kinds of products, environmental conservation, and sustainability (Tachikawa 2005).

These movements were considered to be a change from the production oriented agriculture, which used to be implemented in many developed countries including Japan, to post production oriented agriculture. The change is characterized by a move from intensive to extensive agriculture, from integration to disintegration, and from specialization to diversification (Ilbery and Bowler 1998). A rural area used to be considered an agricultural production space in essence: however, it has become more often regarded as a space with other functions such as leisure and relaxation, cultural and educational values, and environmental conservation, in addition to a place to grow food (Takahashi 1999). While the role of production has decreased in the present rural space, the role of consumption has increased. This situation is defined as the "commodification of rural spaces" (Ilbery and Bowler 1998).

The commodification of rural spaces was developed by rural policy in the Thatcher era in the United Kingdom (Cloke 1992). To be more specific, a market was opened up for various "commodities" such as residential areas, rural communities, rural lifestyle, rural cultures, rural landscapes, and industrial products newly brought from urban spaces besides commoditized agricultural products. According to Woods (2005), "The commodification of rural spaces is exemplified by rural resources that are bought and sold through tourism activities, real estate investment by outsiders, buying and selling of rural products, and the promotion of agricultural products and related products by utilizing a rural landscape image". Thornbury, a small city on the shore of Lake Huron in southern Ontario, Canada is one example. The 
population has increased since the 1980s, and people have been attracted to move to the city from big cities due to its scenic location, pleasant environment, friendly community, and rural characteristics. This is a good example of the advancement of the commodification of rural spaces (Dahms 1996).

Perkins (2006) points out the following specific contents of the commodification of rural spaces: the consumption of "established agricultural and horticultural products" such as dairy products, vegetables, and fruit, the consumption of "new agricultural and horticultural products" which are related to health and fashion issues, migration to suburban areas and development of resort and recreation spaces by counter-urbanization, and utilization of rural land for "recreation and tourism". According to Akitsu (2007), the commodification of rural spaces is defined as a rural area becoming a consumption target by being evaluated as a space for residence, tourism, recreation, and experience. The characteristics of rural commodification vary, but a common trait is that commodification can occur in any area to varying degrees. As a result, the commodification of rural spaces is considered to be an effective means for regional development including tourism and recreation.

At present various types of the commodification of rural spaces are in progress all over Japan. Referring to Perkins (2006), rural commodities in Japan are largely classified into five types. The first type of rural commodities includes established agricultural and horticultural products such as rice, vegetables, fruits, and various kinds of livestock products. Farmers used to supply these commodities stably in huge quantities at a low price. However, recently they have had to change their way of production in response to the consumers who prefer high-quality, safe and secure farm products.

The second type of rural commodities is associated with consumers' lifestyle, health and fashion. There are specifically produced rice, vegetables, fruits, milk, meat, processed foods, health foods, and foods for beauty. Increased consciousness of environment in recent years has led to a growth of interest in the production and consumption of organic, non-chemical and traceable foods. Various kinds of brand foods are also included in this type.

The third is the consumption of rural spaces by counter-urbanization. Many urbanites have moved to rural areas in small communities, while being employed in large urban settings. Those who commute to metropolitan centers by the Shinkansen bullet train are increasing. There are also people who have given up urban life and moved to live in remote rural areas as they can make a living by taking advantage of computers and telecommunications. Some retired people moved to the countryside to start farming and to enjoy rural life. Temporary stay in rural villa or cottage for relaxation is also popular.

The fourth type includes rural consumption for recreation and tourism. Commodified rural recreation and tourism cover various activities ranging from smallscale leisure related consumption opportunities available to local urban residents and tourists in peri-urban areas, to the establishment of significant built environment in rural areas far from cities (Perkins 2006). In the suburbs and peri-urban areas, walking, hiking, farmers' markets, pick-your-own farms, and allotment gardens provide urbanites with opportunities for rural recreation. In the outer fringe of urban shadow, experience farms, farm restaurants, Kleingarten (allotment garden with a small cottage), and Japanese style B \& Bs are main facilities of rural recreation and tourism. In the remote rural areas far from large urban centers, panoramic views of natural environments, hot springs, large-scale ski resorts, swimming beaches, tourist farms, dude ranches, farm museums, country sports parks and so on attract tourists. Remote areas also offer opportunities for new forms of rural recreation such as boating, rafting, kayaking, cycling, mountain biking, fishing, horse riding, and some ecotourism activities.

In addition to the above mentioned four types of rural commodities, there are activities to improve the quality of life through conserving and managing landscapes and natural environments, and through understanding traditional rural culture and society. This is the fifth type of rural commodities.

The largest consumers of rural commodities are urban residents, especially people living in the large metropolitan areas. As the above examples of rural recreation and tourism suggest, the situation of rural areas in relation to large urban centers strongly influence the way of commodification of rural spaces in Japan. Therefore, it is important to discuss rural commodification in terms of urban-rural relationships.

The purpose of this paper is to analyze the possibility of regional development through the commodification of rural spaces in Japan by focusing on the expansion of the tourism factor. Regional characteristics and regional development possibilities in each region will be analyzed by comparing multiple regions with different degrees of tourism development. This paper will clarify the development of tourism in each region and consider 
tourism promotion through the commodification of rural spaces and its connection with regional development. Case studies will be made in three regions: The Nasu region in Tochigi prefecture, which is well known as a traditional hot spring area, the Joetsu region in Niigata prefecture, which has been a high-profile castle town since the age of Kenshin Uesugi in the 16th century, and the Kurobe alluvial fan, Toyama prefecture, which is a rural area with a small tourism base as a whole although major tourism resources including Unazuki hot springs and Kurobe Gorge exist nearby (Figure 1).

The Nasu region, which will be discussed first, ranges from Nasushiobara city to Nasu town and is approximately $140 \mathrm{~km}$ from Tokyo. The population in 2007 was approximately 143,000. It consists of four parts: the northern part of the Yamizo mountain range, Nasu highland, which is a part of Shirakawa hills, Nasu volcano and the Taishaku mountains, and the Nasu alluvial fan, which is surrounded by the previous three parts (Nihon Chishi Kenkyujo et al. 1968) The Joetsu region is located approximately $280 \mathrm{~km}$ from Tokyo by road. It contains the Takada plain where a one day car trip is easily taken from the city center of Takada to the surrounding mountains and hills which are about $5 \mathrm{~km}$ from the border of the plain (Tabayashi and Ishida et al. 2008). The population in 2007 was approximately 196,000. The Takada plain is an alluvial plain of deposits formed by the Seki River and its tributaries (Kubiki Sonshi Hensan Iinkai 1988). The Kurobe alluvial fan occupies the eastern edge of the Toyama plain. It was formed by the Kurobe River whose total stream length is approximately $85 \mathrm{~km}$, and the maximum distance from top to bottom is $13.5 \mathrm{~km}$. It is a well-shaped alluvial fan. The road distance is approximately $390 \mathrm{~km}$ from Tokyo. The development of major irrigation canals on the Kurobe alluvial fan occurred from the 16th to the 17th centuries and most of the area has been converted into paddy fields (Tabayashi 1991). The regional administration area consists of Kurobe city, Nyuzen town and Asahi town and the population in 2007 was approximately 81,000.

This paper focuses on tourism since it can most visually appeal to people, although there are various activities related to the commodification of rural spaces (Cloke 1993). There has been a large number of studies related to
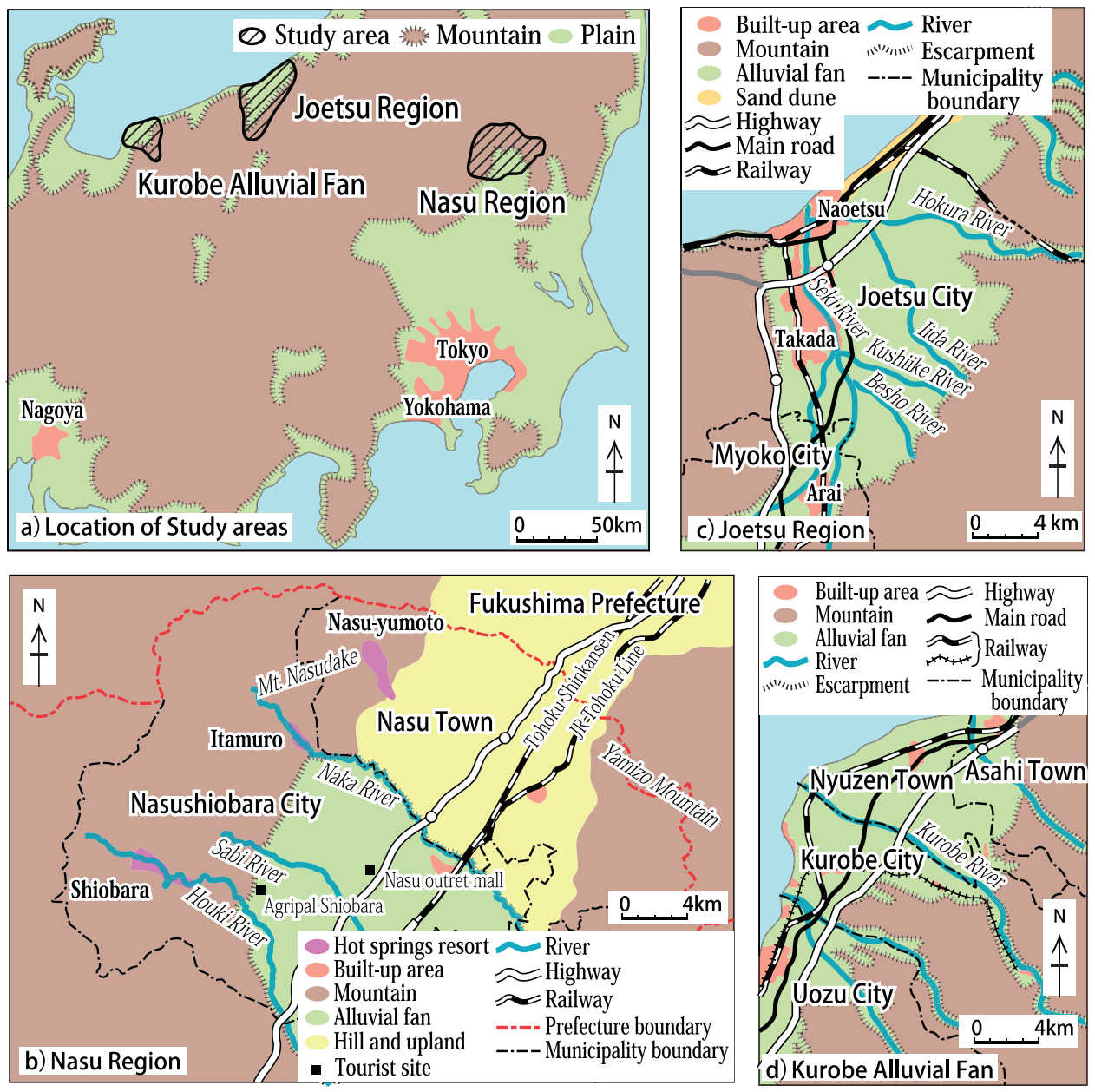

Figure 1. Study areas.

Data sources: Topography maps, tourist brochures and interviews. 
this in Europe and the United States. For example, Butler (1998) points out that while the importance of utilization of rural spaces related to recreation and sightseeing before World War II was low and the influence on rural spaces socially and economically was small, in the late 20th century recreation and tourism became the center of the economy and they began to have an influence on rural society and culture. Woods (2005) argues that the following are major factors of the commodification of rural spaces for tourism: "production place to attract tourists", "rural heritage", "rural landscape as fiction", "experience place such as adventure tourism", and "the use of the rural as a brand to sell goods and products to urban consumers".

\section{Case Study of the Nasu Region in Tochigi Prefecture}

\section{Characteristics of tourist places in the Nasu region}

Although the transition process of tourism in Shiobara hot springs, Nasu highland and the Nasu alluvial fan which make up the Nasu region differ, it is divided into four common periods focusing on tourism styles: first, the period of hot spring and recuperation, when hydrotherapy was the main focus, before the 1950s; second, the period of public hot springs and tourism, when many groups visited on company incentive trips, from the 1960s to the 1970s; and third, the period from the 1980s to the first half of the 1990s, when the number of private visitors and groups increased while various forms of tourism activities emerged. Finally, fourth, is the period of restructuring after the last half of the 1990s, when the number of visitors saw sluggish growth as a whole, and the possibility of a new form of tourism was being sought. On the Nasu alluvial fan tourism activities became more apparent after the 1980s.

\section{Shiobara hot springs}

Shiobara hot springs flourished as a place of recuperation for long stays from the early modern ages to the middle of the 1950s (Shiobara Choshi Hensan Iinkai 1980). When the high economic growth period began, it enhanced its reputation as a public hot springs region with the increasing number of group visitors on company trips. In 1961, Keichozan ski area was established, and the number of ski visitors was expected to increase as well. The peak period of tourism in Shiobara hot springs was during the bubble economy period from the end of the 1980s to the beginning of the 1990s. Before then, the number of visitors had increased from $1,500,000$ to
2,000,000 annually; however, it rapidly increased to $3,500,000$ annually and the number of visitors staying overnight also increased to 1,500,000 annually. In order to handle the increase of overnight visitors, hotel buildings were reconstructed and enlarged. In addition, the "Hunter Mountain Shiobara Ski Resort" was opened at the foot of Mt. Myoujingatake in 1987, and the number of ski visitors increased.

The collapse of the bubble economy caused serious damage to the tourism business in Shiobara hot springs. The number of tourists which had begun to decrease in 1996 temporarily increased in 2001; however, since then it has remained unchanged. The number of overnight tourists has been on a downward trend since its peak time in 1990, and in 2007 fell to below 1,000,000. In order to reverse this trend, the "Momijidani Suspension Bridge" was constructed over the Houki River in 1999, and "Hananoyu", a public bathing facility, was constructed in the Kami Shiobara district. A foot bath was also built there in 2002 and 2004. Also, the following three facilities were opened: an exhibition room to display historical papers related to the literati who visited Shiobara hot springs, the Shiobara Story Museum (Shiobara Monogatari Kan) "in 2003, annexed to a restaurant serving dishes cooked with local farm products, and in 2006, "Yuppo no Sato", a cloister style foot bath facility with a total length of $60 \mathrm{~m}$.

Shiobara hot springs consists of 11 hot springs that are spread across the area with a $350 \mathrm{~m}$ vertical drop along the Houki River and its tributaries, and these hot springs have different characteristics (Figure 2). They are classified into four types with different features (Adachi, et al. 2006): (1) beautiful valley and artistic remnants (2) hot springs resort, (3) rural landscape and (4) secluded hot spring spot. Hotels are located along the Houki River in Ooami, Shiogama, Fukuwata, and Hatashita, and guests have a great view of the valley. The hot spring resorts atmosphere is very noticeable in Monzen and Furumachi. Hotels, souvenir shops, and restaurants stand in line along Route 400 in these areas. Fields of highland daikon radishes and rice paddies surround the hotels in Kamishiobara and Nakashiobara, which creates an idyllic atmosphere. Shionoyu, Arayu, and Motoyu are visited by people who have escaped from the bustle of the city, in order to appreciate the atmosphere of a secluded hot springs spot. These three areas are all located in mountainous areas where the origins of the tributaries of the Houki River are and therefore, words such as "secluded hot spring atmosphere" or "hidden hot spring" are used to explain their location. 


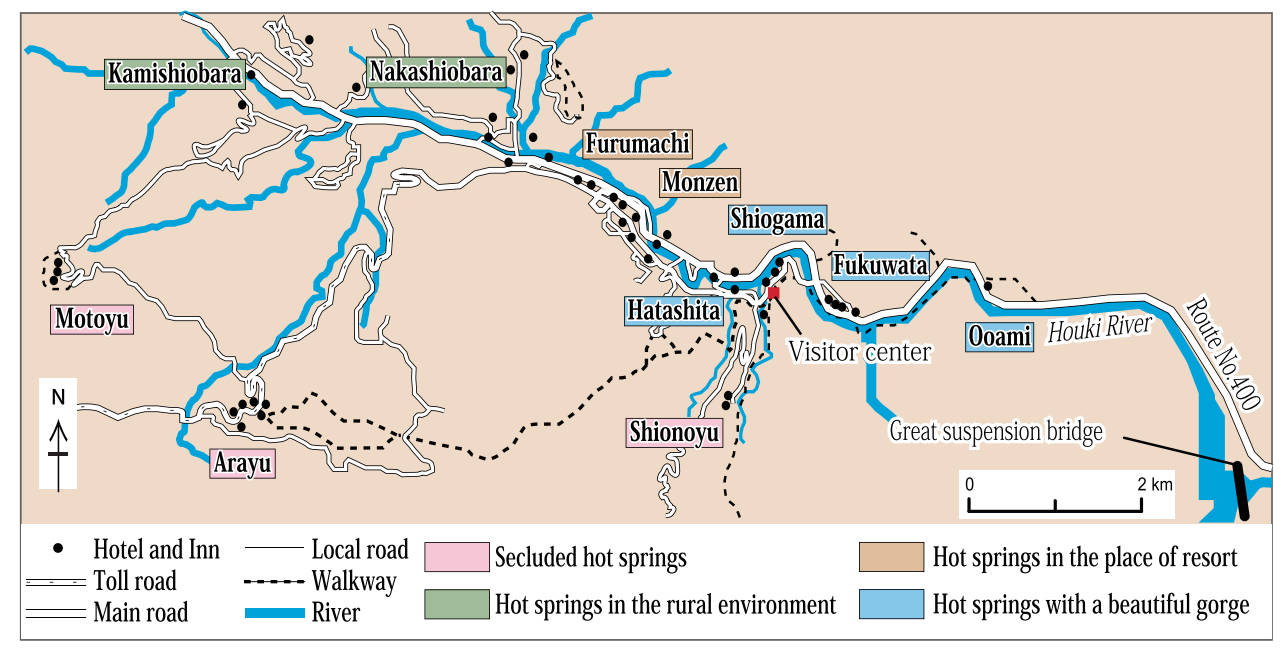

Figure 2. Characteristics of Shiobara hot springs as a tourism area.

Data sources: Topography maps and interviews.

\section{Nasu Highland}

Recuperation was originally the main traditional activity, although there was climbing for mountain worship as a leisure activity in Nasu highland (Nasu Machi Kyoiku Iinkai 2005). After the period of high economic growth was established in Japan, the period of public hot springs began in Nasu highland. In particular, Nasudake Ski Resort operated by Nasu town was established in 1960, and the Nasu Gondora was built in 1962. Therefore, mountain climbers, hikers, and skiers who were not interested in mountain worship began to visit Nasu highland. At the same time, Rindo Lake Family Ranch was opened, and Minamigaoka Ranch was upgraded for tourism purposes. Furthermore, "Nasu Royal Center" was constructed by Fukushima Kotsu (a bus and train company) in 1968, and leisure and amusement facilities such as "Nasu Highland Park" were constructed by Towa real estate agency in 1969. As a result, the number of tourism facilities utilizing the image of a highland and a ranch increased in Nasu highland and Nasu highland as a tourism complex was shaped.

Full scale villa developments using capital from major real estate companies started in Nasu highland after 1972. In the late 1970s, Japanese style B \& Bs began to be located between these resort villas. In 1980, "Nasu Safari Park" was opened, and leisure facilities targeting family tourists were continually being constructed. A characteristic from the late 1980s to the early 1990s was the rapid increase of small art galleries and museums. These facilities display classic cars and music boxes, and one can experience cloisonné work. In 1994 the "Mt. Jeans Ski Resort Nasu" was opened.

As mentioned so far, while tourism in Nasu highland has diversified, the number of day trip visitors has increased with the recent opening of highways and building of the Shinkansen bullet train line. In addition, the number of overnight visitors at dormitories and resort hotels owned by private companies has decreased due to the collapse of the bubble economy. The number of visitors staying in campsites which play a role of both accommodations and leisure facilities has increased since the mid 1990s, and there has been a trend to increase the opportunities for experience-based tourism.

At present tourism facilities radiate out from Nasuyumoto hot springs (Figure 3). There are traditional hotels on the west side of the road running from south to north in Nasu-yumoto area. Hotels are near the mountainside and western area, and Japanese style guest-houses stand on the east side of the road. Souvenir shops are scattered among these accommodations. Okunasu hot springs is in the north of Nasu-yumoto, and it consists of Daimaru hot springs, Kita hot springs, Benten hot springs, and Asahi hot springs.

There is an extensive large scale villa resort development built using external capital in the south of the Nasuyumoto area, and various tourism facilities such as the following are located around these large villa resort areas: Japanese style B \& Bs, guest-houses, company dormitories and resort facilities, leisure facilities, art galleries, and museums. In addition, among these tourism facilities, private villas have been constructed. Major hotels and leisure facilities, built by external capital, and art galleries, museums, and souvenir shops stand between the south of these areas and Route 68. In recent times more farm households have started to offer tourists farming experiences and have sold them home-made ice cream, which helps to enhance the image of "highland resort". As mentioned above, Nasu highland as a tourism area has the 


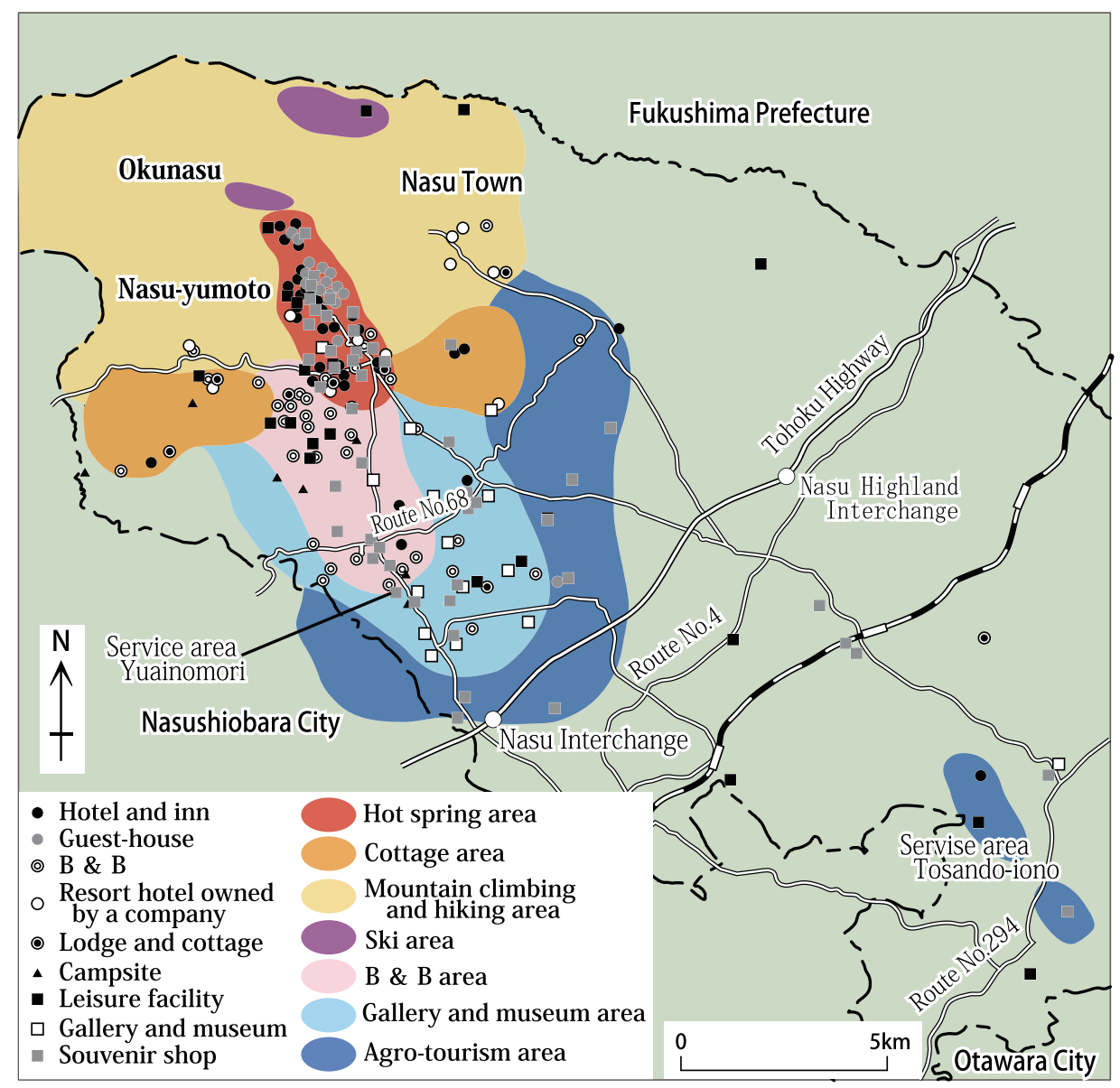

Figure 3. Characteristics of Nasu highland as a tourism area.

Data sources: Topography maps, tourist brochures and interviews.

characteristics of an integrated place of tourism centering on a hot spring area with various tourism facilities spread out in a concentric pattern.

\section{Tourism development owing to the commodification of rural spaces in the Nasu region}

\section{Shiobara Hot Springs and its periphery}

Shiobara hot springs has a rich natural environment and rural resources. Natural pathways have been developed such as construction of suspension bridges, which showcase the natural environment for tourism. At present there are 25 large and small waterfalls and 9 suspension bridges, and 12 natural paths were constructed to tour this area. Examples of rural resources in Shiobara hot springs are the rural landscapes and highland daikon radishes in Kamishiobara and Nakashiobara. Shiobara hot springs had long been portrayed as a hot spring area, and the introduction of tourism based on fine dining and locally produced food has been an issue for a long time. However, this culinary development has been accepted with the establishment of a restaurant utilizing local farm products in "Shiobara Monogatari Kan", and with the high quality of dishes serving local farm products in each hotel.

As mentioned above, in order to offset the downturn in hot springs tourism, there has been an attempt to make use of natural environment and rural resources. Health tourism had been envisaged by the Chisan Chisho (local production for local consumption) Committee of Shiobara Hot Springs in its Health Promotion Plan, which has been in effect since 2006 and was created through a collaboration of government, the tourist association, the hot springs hotel association, and local companies. It was defined as "Shiobara Hot Springs Health Promotion Tour" and received financial assistance from the Ministry of Land, Infrastructure, Transport and Tourism, as a "New tourism creation and distribution promotion business" in 2007. The purpose of this new form of tourism is to promote health through spa therapy, climate therapy, nature walks, and meals using local farm products. The difference from the conventional hot spring experience is that patrons receive enhanced benefits by following a personalized therapy schedule based on medical examinations and doctors' recommendations.

Agripal Shiobara is a facility annexed to a restaurant, 
and it uses a local market to obtain locally produced farm and specialty products. It was established in 1996 with the financial assistance of the Ministry of Agriculture, Forestry and Fisheries of Japan, "Agricultural Structure Improvement Project for Agriculture and Rural Village Promotion (create demand type)". Agripal Shiobara is operated by "Agripal Shiobara Organization," consisting of local farm householders. It has three subordinate organizations: a local farm product cooperative, Kaze Monogatari and Momiji Village, and Seki no Sato. The local farm products cooperative consists of 134 individual members who are mainly local farm households and seven organizations including nursery companies and a forestry cooperative, and these members ship farm products to Agripal Shiobara. Kaze Monogatari and Momiji Village is an organization with seven full members and five associate members that aims to produce high value added processed products by using local farm products. Seki no Sato consists of six members and nine associate members, and they run a restaurant serving meals prepared with local farm products.

\section{Nasu Highland}

Agriculture has recently been incorporated into tourism in Nasu highland. Farmers' markets and farm restaurants are connect tourism facilities such as hotels and farmers, and hence the creation of agri-tourism. Furthermore, in addition to tourism facilities such as Minamigaoka Ranch, individual farm households have been attempting to operate farms for tourism, a market for farm processed products, and a place to experience farming experience. In Nasu town a film commission was organized, and the filming of movies and television programs has been conducted on such ranches and highlands. Activities of this film commission are connected to the promotion of the whole Nasu highland.

At present Minamigaoka Ranch is representative of a tourism ranch in Nasu highland. It was originally established by the father of the current owner when he moved to Nasu town from Manchuria in 1948. A few years after the father started the ranch, the operation's focus was converted from crop cultivation into dairy husbandry, and even then, the ranch was promoted as tourism places from the 1950s to the 1960s (Minamigaoka Bokujo 1998). As of August 2008, the scale of operating farm was as follows: 50 dairy cattle, 22 to 25 beef cattle fattened up annually, approximately 5 ha of farmland focusing on vegetables and feed stuff, 10 ha of meadow, and 10 ha of pasture. Over $90 \%$ of farm products are directly sold to tourists, and the rest are shipped to the Ohtawara branch of the Tobu department store or confectionary shops in the Nasu region and its surrounding area.

There are two previously mentioned Michi-no-eki ("Road Station", a rest area at the side of a highway) in Nasu town, and each has a market for local farm produce. Since the number of customers of both markets is high in summer and is consistent with a shift in tourists per month in Nasu town, tourists are considered to be the main customers. "Fureai no Sato Market" was opened in April 2005 and is set up in Michi-no-eki at Nasu highland Yuai no Mori, located approximately $5 \mathrm{~km}$ south of Nasuyumoto. Vegetables shipped by the 70 members are mainly sold at the market. The average sale proceeds per member is 200,000 to 250,000 yen a month, and it greatly accounts for the income of shipping farm households. In addition, a farm restaurant, called "Nasutaurant" is set up at the Michi-no-eki for the purpose of consuming locally produced farm products in Nasu highland.

The other market for local farm products is "Furusato Bussan (local specialized product) Center", and it is located along Route 294 in the southern part of Nasu town. This opened in November 2000 and is annexed to the Michi-no-eki, "Higashi Tosando Iono" built for the purpose of regional development in the Iono area. Besides a market, there are several other facilities: a folklore exhibition building, a facility for experiencing buckwheat soba noodle making, a water mill, and a soba restaurant. In 2007 , the total sales was $380,300,000$ yen (100 million yen for soba restaurant, 120 million yen for the farm products, 100 million yen for farm processed products, and 25 million yen for the tea shop). Most of the customers on weekends are tourists, while on weekdays they are proprietors of resort inns, cottages, and local restaurants. There are some customers from nearby golf courses spending approximately 10,000 yen on souvenirs for themselves. The customers are mostly middle aged in their late 50s.

Some farm households participating in the above two markets are also involved in two other tourism projects: the "Nasu Highland Experience Program" and "Nasu Brand". The "Nasu Highland Experience Program started in 2005, and is divided into five experiential themes dealing with ranching, tasting, nature, agriculture and forestry, and craft making. Dairy farm activities consist of milking cows and feeding calves, ranch walking, and butter making. Most of the tourists visiting the dairy farm are families, and local elementary school students and those from Nikko city also visit annually. 


\section{Nasu Alluvial Fan}

Major development of the Nasu alluvial fan started in the Meiji era. After 1878 many large farms were established by government officials and local leaders (Nishi Nasuno Choshi Hensan Iinkai 2000). In addition, Nasu irrigation canal was completed, taking its water from the Nasu River in 1885. The main trunk of Nasu irrigation canal is approximately $16 \mathrm{~km}$, the total length of adjoining aquaducts is approximately $46 \mathrm{~km}$ and it has contributed to agricultural development on the Nasu alluvial fan (Nasu Sosui Hyakunenshi Hensan Iinkai 1985).

Recently, activities that use farm and rural resources have been promoted on the Nasu alluvial fan. The old water intake facility of Nasu irrigation canal, which was designated as a cultural asset of national importance in 2006, is a significant example of using a historical site related to agriculture. In the Naka River, in the west Iwasaki area of Nasushiobara, a weir which takes the water into Nasu irrigation canal was established. An old water intake opening was used at the upstream side from 1905 to 1976. This place was developed into the Nasu Water Intake Park from 1998 to 2001, and one can understand its history through the remains of waterways and a floodgate (Figure 4). In addition, the weir, irrigation network, and a water diversion facility supporting the current Nasu alluvial fan are important resources to illustrate the pioneering history on the Nasu alluvial fan. Apart from them, facilities which illustrate local livelihood and culture such as the following have been prepared: Matsukata Town House, Nogi Town House, old Aoki Town House in Nasu, town houses of pioneers, Nasunogahara Museum, and Kuroiso Local Resource Center.

Furthermore, in order to attract more tourists, farmers' markets and events related to farm experience have been developed (Figure 5). Markets for local farm products are located in the surrounding urban district of old Kuroiso city and old Nishi Nasuno town and along the road running from the Nasu alluvial fan to Nasu highland. Farm experience activities include milking cows, cheese making, strawberry and blueberry picking, and soba noodle making. In addition, a farmers' market and a tourism information center targeting the whole Nasushiobara city were set up in the Nasu Garden Outlet that was opened in July 2008 in the old Kuroiso city. Senbonmatsu Ranch's operations exemplify these farm experiences and involve a great number of visitors.

Senbonmatsu Ranch is located on the farmland of a transfer of government property to Iwao Matsukata, a son

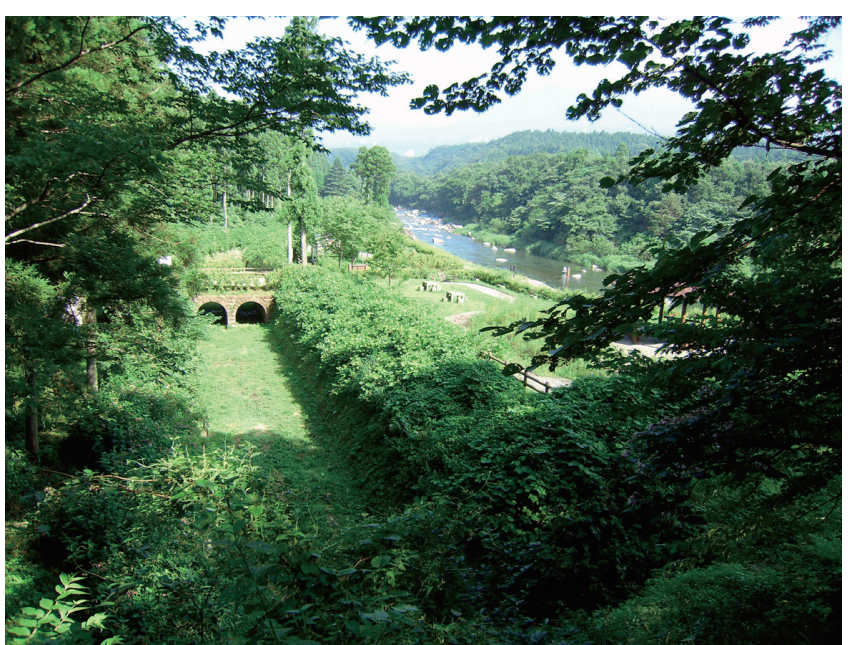

Figure 4. Old water intake facility of Nasu irrigation canal.

Taken by the author, August 2008

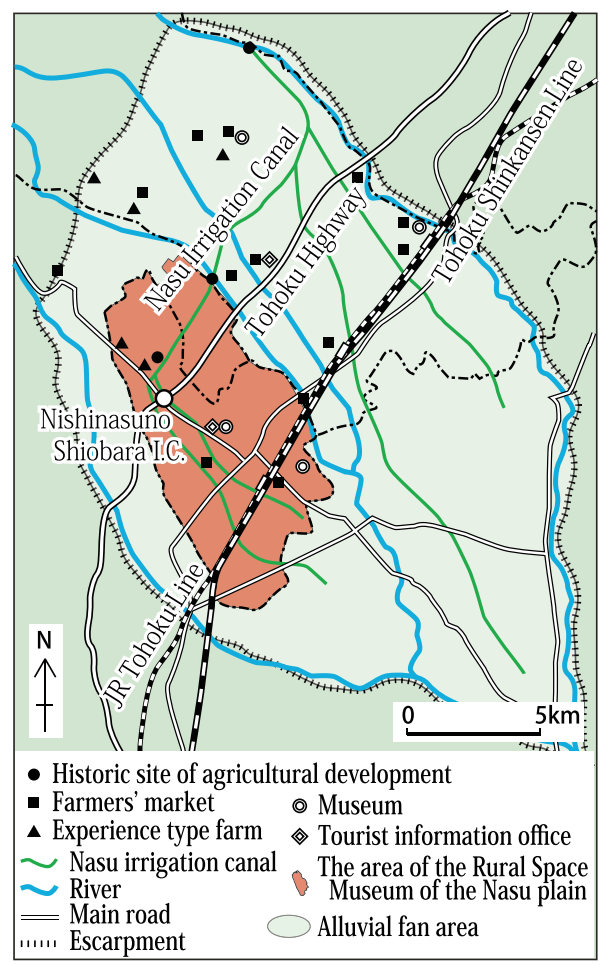

Figure 5. New tourist resources owing to the commodification of rural spaces on the Nasu alluvial fan.

Data source: Field survey.

of Masayoshi Matsukata, and it was demolished by the Nasu Development Company in 1893. In 1928, the farm was taken over by Horai Shokusan Inc. The present area is 831 ha. Senbonmatsu Ranch introduced dairy cattle from Hokkaido and launched a dairy business after World War II. Even now dairy is one of the primary businesses at Senbonmatsu Ranch; pasture accounts for most of the ranch, 550 Holstein cows are raised, and approximately $8 \mathrm{t}$ of raw milk per day are produced. Raw milk is processed 
into ice cream, yogurt, and other dairy products, which are sold. In addition, Senbonmatsu Ranch is involved in farm experience tourism such as milking cows, as well as selling souvenir and operating two golf courses. There is parking for 1,100 ordinary vehicles within the ranch.

The Rural Space Museum Project was created by the Ministry of Agriculture, Forestry and Fisheries of Japan and is centered on old Nishinasuno town. This project allows local resources related to agriculture and rural villages on the Nasu alluvial fan to be used for tourism purposes. The Rural Space Museum Project reevaluates historically and culturally traditional agriculture facilities and rural landscape as local resources. Management of such resources is undertaken by local residents on their own accord, and as a result, history education and interaction between urbanites and rural villages takes place while observing nature.

A primary role of the Rural Space Museum Project was route planning to combine local agriculture and rural resources and to preserve them as satellites: one or two routes were established in each community, and the Rural Space Museum Project Team of each community was assigned to manage them. By 2006, 101 satellites were designated and prepared, eight routes where people can walk around satellites in each community and two routes where people can see around satellites by car spending half a day or one day, were established. In 2004 a general information center of the Rural Space Museum Project was opened in the newly built Nasunogahara museum. Posters and brochures describing the project are available at the information center. Routes and satellites prepared by the rural space museum project are used in community activities. In addition, the number of new residents commuting to Tokyo area has increased since the opening of Nasushiobara Station on the Tohoku Shinkansen line. The Rural space museum project also encourages new comers to understand the history of the Nasu region and be integrated more into the community.

\section{Formation of a broad and diversified tourism region owing to the commodification of rural spaces}

Shiobara hot springs and Nasu highland have represented tourism in the Nasu region since old times and have attracted a great number of tourists owing to the hot spring, and the number of tourists flourished in the 1970s (Figure 6-a). In addition to group visitors, the number of individual and family visitors increased from the 1980s to the early 1990s. Large-scale accommodations that have been renovated and expanded were promoted in Shiobara hot springs, and a greater number of visitors has been the result. At the same time in Nasu highland, villa development was promoted, and Japanese style B \& Bs filled the gaps between resort villas. Leisure facilities were also improved. Each tourism area in the Nasu region peaked during this period (Figure 6-b). As well, Senbonmatsu Ranch on the Nasu alluvial fan began its tourism operations.

The number of tourists started to decrease at every tourism area when the bubble economy collapsed at the beginning of the 1990s. In response, Shiobara hot springs and Nasu highland began to seek tourism development by utilizing natural landscape, agriculture and rural resources as well as further improving tourism facilities: establishment of natural walkways, launch of markets for local farm products, and introducing farming experience programs and health tourism. As tourism business expanded on Senbonmatsu Ranch on the Nasu alluvial fan, Nasunogahara Museum was built. Moreover, the Rural Space Museum Project was implemented to promote and save daily agriculture and rural landscapes as cultural heritage (Figure 6-c).

As a future vision of the Nasu region, it is essential for individual tourism areas including Shiobara hot springs, Nasu highland, and Itamuro hot springs to create and form various broad tourism areas with mutual tourism collaboration as well as to promote tourism development by using each regional characteristic. The utilization of agriculture and rural resources enables a tourist area to expand by enlarging individual tourism places outward and filling spaces between tourist sites (Figure 6-d). The value of the Rural Space Museum Project focusing on old Nishinasuno town is widely recognized, and the trend to promote the use of the following in tourism has been strengthened: Nasu irrigation canal and adjacent rice paddy, various historical sites, museums, markets for local farm products, food culture, farming experience, and the whole rural landscape. These changes are important in terms of escaping from urban life and enjoying extraordinary experiences. Specifically, it is increasingly important to respond to the demand of green tourism, eco-tourism or cultural tourism. That is, it is expected that new tourism areas will be developed by commodifying of rural spaces (Tabayashi and Tanno et al. 2008). 


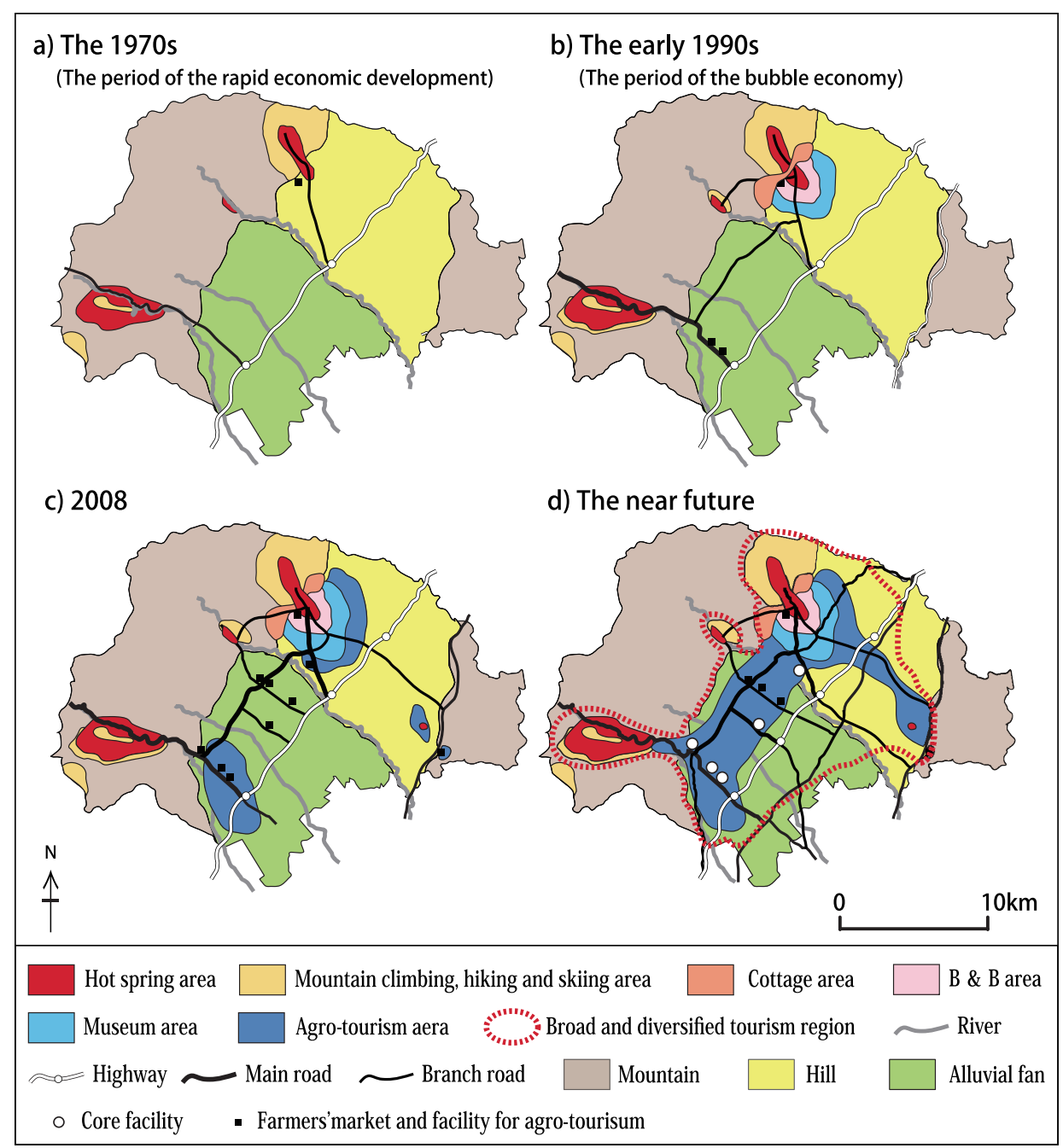

Figure 6. Formation of a broad and diversified tourism area owing to the commodification of rural spaces in the Nasu region.

Data source: Tabayashi and Tanno et al. 2008.

\section{Case Study of the Joetsu Region, Niigata Prefecture}

\section{Tourism trend and tourism resources}

\section{Tourism trend}

The current Joetsu city area was established by the merger of old Joetsu city and 13 towns and villages in January 2005. The number of tourists in the current Joetsu city area was $4,635,000$ in 1992 ; however, it decreased to $4,141,000$ in 1999 due to the deterioration of the entire Japanese economy. Since then tourism promotion has been emphasized even more by the Joetsu city mayor, and in 2005, two divisions were set up: a tourism promotion division which administrates and operates existing tourism facilities and plans tourism related events, and a tourism project division which conducts future plans and projects. The number of tourists visiting Joetsu city increased to $6,726,880$ in 2006.
According to a survey conducted by the tourism promotion division of Joetsu city, $36.4 \%$ of all the tourists visiting Joetsu in 2006 came from outside Niigata prefecture. The largest number of tourists visiting Joetsu was 1,247,080, and they were from the Tosan and Tokai (Yamanashi, Nagano, Gifu, Aichi, Mie) regions. The number of tourists from the Kanto region, especially Gunma, was 717,260, which was also large.

\section{Natural tourism resource}

In the "Five year project of the third tourism promotion strategy in Joetsu", tourism resources in Joetsu are classified into natural tourism resources, cultural tourism resources, and tourism facilities (Joetsu City 2006). As natural tourism resources, the following swimming beaches are firstly considered: Naoetsu, Tanihama, Unohama-onsen, and Chuo. These four beaches along the Sea of Japan are crowded with sea-goers from inland prefectures such as Nagano, Gunma, and Yamanashi. 
In addition, although a lagoon behind dunes and surrounding mountains and highlands are mentioned, the number of natural tourism resources is small as a whole. The whole length of the Katamachi dune from Kakizaki to Naoetsu is $15 \mathrm{~km}$, and the largest width is $2.5 \mathrm{~km}$. There is a magnificent view of Sado island from Hikarigahara highland 700-1,100 meters above sea level and tourists are able to appreciate the natural landscape.

\section{Cultural tourism resource}

The most significant cultural tourism resources are historic sites related to the 16th century civil war commander, Kenshin Uesugi. These are resources only the Joetsu region possesses, and were featured in recent NHK period dramas such as "Shingen Takeda" and "Tenchijin (Kanetsugu Naoe)", and have received a fair amount of attention. The ruin of Kasugayama Castle which was the official residence of Kenshin Uesugi and Kasugayama Shrine, which was considered as a local deity of Kasugayama Castle, are particularly notable. After Kasugayama Castle was deserted, the castle town was relocated since Hori constructed Fukushima Castle in the Naoetsu area; however, since Takada Castle was constructed as a residence of Tadateru Matsudaira, the 6th son of Ieyasu Tokugawa, in the Takada area in 1614, the castle town was relocated again. The structure of a modern castle town is well reflected in the present face of streets in Takada. The castle town was established surrounding the north, west, and south sides of the castle, and senior statesmen's houses were allocated near the castle surrounded by ordinary samurais' houses. A merchant district was allocated on the north, west, and south sides of samurais' houses and a temple district was allocated in the far west. In the merchant district extra long eaves were installed with edges of the eaves of private properties covering the alleys used as public streets, and they still remain at present. A large number of historical sites related to Shinran Shonin (the founder of the Jodo Shinshu Sect of Buddhism, 1173-1262) exist, and the representative examples are as follows: Kotagahama, where he landed when he was exiled to Echigokokufu in 1207 (embarkation point of Shinran Shonin), Gochikokubun Temple, a residence of Shinran Shonin and Jyoko Temple, where the remains of Shinran Shonin are interred.

Events and festivals are also included in cultural tourism resources. The Lerch Festival is held at Mt. Kanaya, commemorating the event when Major von Lerch introduced skiing to Japan. The ruin of Takada Castle with approximately 4,000 cherry trees is crowded with tourists in the cherry blossom viewing season and Takadajo Hyakumannin Kanosai (The cherry blossom festival viewed by a million tourists at Takada Castle). The lotus flowers in the outer moats of Takada Castle are considered to be the most famous in the Orient, and both cultural and sports events are held at the Joetsu Lotus Festival. There are also other festivals such as the Joetsu Festival, a Gion festival which connects Takada and Naoetsu districts, and the Kenshin-ko Festival, honoring the heroism and morality of Kenshin Uesugi.

\section{Tourism facility}

Unohama hot springs was discovered when Teikoku Oil Co., Ltd was exploring for resources in 1958, and it has sodium chloride springs. There are 11 hotels and four guest houses in Unohama hot springs. There is also a one day hot spring facility called Unohama Mermaid House. There are seven major art galleries and museums: Joetsu Buried Cultural Property Center, displaying excavated articles that introduce the region's history; Eshin no Sato Commemoration Hall, displaying historical materials associated with a wife of Shinran Shonin, Nun Eshin; Kasugayama Historic Place, where Kenmotsu and Yagen moats and watch boxes were restored to their original states; Kasugayama Monogatari Kan which is adjacent to Kasugayama Historic Place; Maejima Memorial Museum, displaying items belonging to Hisoka Maejima who is called the father of Japanese Postal Service; Division Commander's Residence, where Gaishi Nagaoka who was the 13th division commander lived; and the Japanese Memorial Museum of Skiing which is on top of Mt. Kanaya with the statue of Major von Lerch.

As for leisure and amusement facilities, there is the Ocean Fishing Center. This is a 185 meter long pier which extends into the Sea of Japan and a fishing reef that was installed around the pier. There are a total of 10,000 fish, consisting of 400 species, displayed in Joetsu Municipal Aquarium. As previously mentioned, Mt. Kanaya ski area is the birthplace of skiing where Major von Lerch, who was Austrian, taught skiing in Japan for the first time in January 1911. The number of skiers has decreased: however; the facility is popular with local elementary school students since they can enjoy the super slide with two 450 meter long tracks in all seasons except winter. Wild birds and plants can be observed in Gochi Park, and over 700 double-flowered cherry trees can be viewed from late April to early May.

The Joetsu region has been the home of Echigo Toji. Echigo is an old name of Niigata which is still often used, and Toji means the head brewer or sake master, 
and there are many sake brewing related facilities. Sakaguchi Memorial Hall is a facility which introduces the sake brewing culture of Kubiki Toji as well as praising the achievement of Kinichiro Sakaguchi who was an internationally respected authority of applied microbiology, also known as the "Sake Professor". In Yoshikawa Toji no Sato tourists are able to see manufacturing processes of local sake and dairy products and are able to taste and purchase products. Kome to Sake no Nazo Kura (The Rice and Sake Warehouse of Wonder) is a museum with a rice and Japanese sake theme, and is located in the hilly eastern area of the Takada plain. In 1890 Zenbe Kawakami opened Iwanohara Vineyard in a barren hilly area at the eastern edge of the Takada plain, and later he was called "The Father of Japanese Wine". At Joetsu Bussan Center over 600 products are sold, such as items related to Kensin Uesugi who is associated with Joetsu city, Sasadango (red bean and rice in bamboo leaves), seafood, confectionaries, and sake. Many tourists visit to purchase souvenirs.

The Region Plaza Joetsu is another complex which was opened as a Joetsu municipal facility in 1984 in order to promote health and physical strength of citizens and conduct various recreational, art, and cultural activities. The Culture Center for Youth and Children is also a facility mainly to enhance education, culture, and the health of youth in the city.

Four morning markets are held in Joetsu city: two in Takada, one in Naoetsu, and one in Kakizaki. Ohmachi 3 chome has Nishichi no Ichi (a market opening on the 2nd, 7 th, 12th, 17th, 22nd, 27th of every month) and Ohmachi 4 and 5 chome has Shiku no Ichi (a market opening on the 4th, 9th, 14th, 19th, 24th, 29th of every month) in Takada region. Most of the stands sell groceries such as vegetables, dried fish, and confectionery at a morning market, and most of the customers are local residents, especially senior citizens. Most of the fresh food markets were closed in the built-up area owing to the proliferation of shopping centers in suburban areas and therefore, these morning markets are essential for senior citizens (Figure 7).

\section{Distribution of tourism resources}

According to the distribution of tourism resources on the Takada plain and its surrounding areas and the number of tourists in each place in 2006 (Figure 8), tourism facilities such as the following have been successful in attracting 100,000-500,000 tourists annually e.g., bathing beaches, hot springs, an aquarium, Region Plaza Joetsu, and Joetsu Bussan Center. Cultural tourism

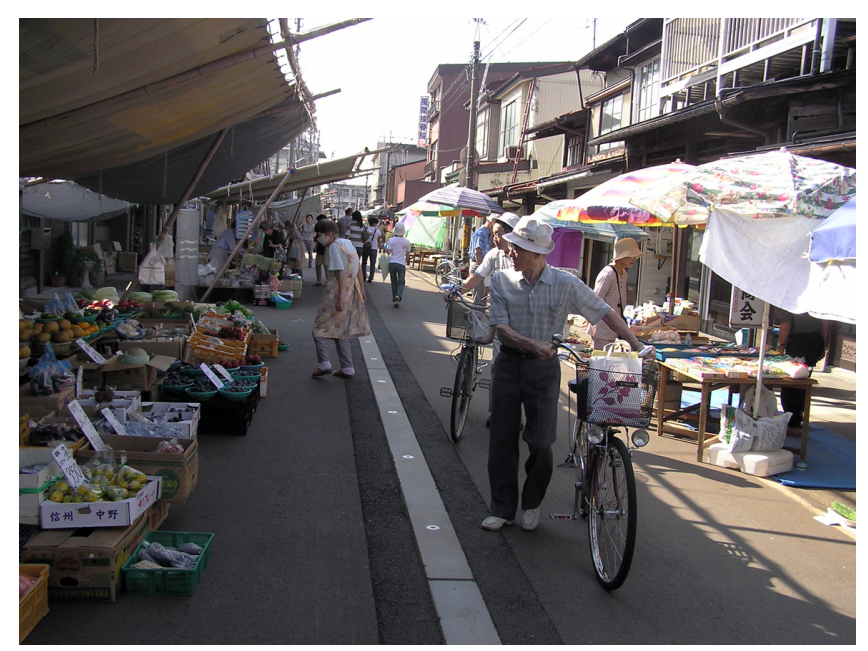

Figure 7. Morning market (Nishichi no Ichi) in Takada, Joetsu city.

Taken by the author, September 2007.

resources attracting the equivalent number of tourists to the above facilities are only the ruins of Kasugayama Castle and Rinsen Temple with over 377,020 tourists. These are located along the Sea of Japan and are concentrated in the Naoetsu and Kasugayama areas. Although there are many tourism resources in Takada urban district, only Kanayasan Park (56,990 tourists) and Takada Park (36,880 tourists) are notable. However, although it is not shown in Figure 8, the Takada region has the ability to pull in more visitors with regard to events and festivals such as follows: Takadajo Hyakumannin Kanosai held in the ruin of Takada Castle in April attracts 798,100 tourists, Joetsu Lotus Festival held from late July to early August takes in 120,000 tourists, Joetsu Festival with the collaboration of Naoetsu and Takada regions has 355,600 tourists, and Joukamachi (castle town) Takada Flower Road has 33,000 tourists.

Although cultural tourism resources and tourism facilities are distributed randomly in other rural villages in the Takada plain and hilly districts, the number of tourists visiting these areas is small, apart from the following three: Iwanohara Vineyard with 51,390 tourists, Yamamoto Vineyard with 42,600 tourists, and Yasuragi-so (hot springs) with 41,870 . As mentioned before, tourism resources that are attractive to tourists are located only in built-up areas and along the coast, and tourism resources generally have not been used efficiently.

\section{Characteristics of tourism resources}

In recent years various tourism facilities have been built near natural and cultural tourism resources in the Joetsu region. In particular diverse tourism resources are managed under one governmental body due to the merger 


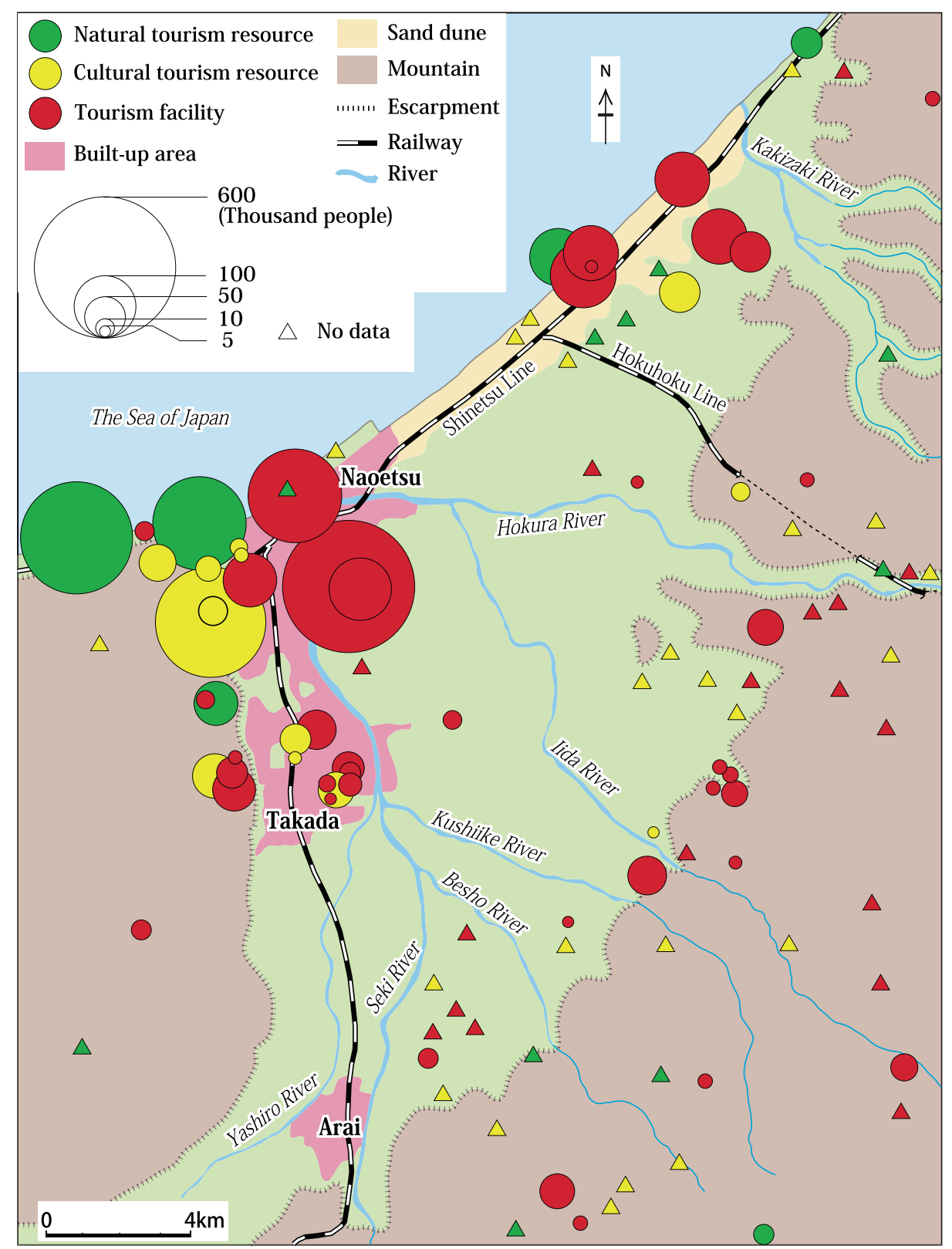

Figure 8. Distribution of tourism resources and tourists in the Joetsu Region.

Data source: Tabayashi and Ishida et al. 2008.

of 14 municipalities in 2005. The first characteristic of the tourism resources is their large number and diversity.

The second characteristic is that the scale of each tourism resource is comparatively small, and there are few resources that attract tourists "just to see them" (Joetsu City 2001). The third characteristic is the decentralization of tourism resources. This is related to unimproved infrastructure of public transportation and the large size of the region; however, the regional consolidation, and organized condition are insufficient, which is a main issue. Fourth, there exist many regional resources that are not well recognized as tourism resources but have possibilities. Examples are, the natural environments such as sea, mountains, and snow. Also, cultural landscapes such as the castle town and rural villages, and cultural characteristics such as various lifestyles and food have potential to draw tourists. The issue is how regional resources are utilized, and the important key is the commodification of rural and urban spaces.

The characteristics of tourism have changed in response to changing times. Until recently, tourism had involved mostly visiting and enjoying tourism places and facilities; however, "educational tourism" and "experiential tourism", discovering the peculiarities of each regional landscape and lifestyle, and experiencing and learning about them on site, has entered into the limelight. In 1999 the Joetsu Countryside Experience Project where visitors stay in a farm house and experience farming was launched, 
targeting groups such as elementary, junior high and high school students in the six municipalities of East Kubiki County at the time. This is focusing on learning from local nature, lifestyle, and people with the aim of regional vitalization. This program has continued even after the merger with Joetsu city.

When considering tourism development in the Takada plain and its surrounding areas, future issues such as the following must be included: mutual collaboration of various small-scale scattered tourism resources, the incorporation of regional resources, and the utilization of educational and experiential tourism in order to actualize the first two issues previously mentioned.

\section{Tourism development owing to the commodification of rural and urban spaces}

One of possibilities of regional resource utilization is the discovery of new tourism resources by the commodification of rural and urban spaces. The rural and urban spaces in the Joetsu region are the places where ordinary residents perform their normal daily activities; however visiting tourists find these life spaces to be distinctive and interesting. They are widely distributed and therefore, the collaboration of conventional scattered tourism resources can take place through promotion to make them tourism resources (Tabayashi and Ishida et al. 2008).

First, the castle town in Takada can be identified as urban space, whereas, as previously mentioned, the urban planning in the early Edo era was definitely considered as a stimulus for the current urban structure. The structure of the castle, samurai houses, a merchant town, and temple town still exists at present. Moreover, places that constitute the urban area also have enormous appeal. For example, tourists enjoy seeing the structure of the castle town, landscape characteristics such as eaves and ladders for snow removal, and the canal in the merchant town, the morning markets where people can shop for fresh vegetables and other farm products and enjoy talking with street vendors, and the temple town where 66 historic temples are located.

Urban spaces from ancient to present times form layers on the Takada plain. It is also interesting to study and understand it. The oldest is the urban space from ancient to medieval times centered on Kokufu (the exact place is unknown) in the Naoetsu region where Kokubunji Temple and many historical sites still remain. The second oldest is the urban space from the late medieval period to the Warring States period, which focused on ruin of Kasugayama Castle and there are also many other remaining historical sites. The third urban space is the more recent castle town in Takada, and the fourth urban space corresponds to the present business district centering on the current city hall and a large scale commercial facility near the interchange of the Hokuriku Expressway.

Rural space examples are a landscape of farm villages and paddies spread through the whole of the Takada plain; Nakae, Uwae, and Ohbuke irrigation canals which were developed in the Edo era. Farmers diligently built these canals by amassing enough capital and workforce, and therefore they have value as cultural assets. Holding ponds in downstream areas of Uwae irrigation canal in Sanwa district were able to be filled with water only at night due to the custom of water use that had continued since the Edo era until the completion of the National Seki River Water Use Project in 1984. These holding ponds were developed to impound water temporarily and to supply water into each paddy field during the day time. When agricultural development began due to the stagnation of the salt and fishing industries, which had been the primary source of work for those living in Katamachi dune area at the end of Meiji era, a communal forest was converted into dry fields. The remains of land division can still be seen at present. Large and small lakes behind Katamachi dune are the remains of Ohgata lagoon from the early Edo era. The remains of a landslide in East Kubiki hilly area can be seen, and a large number of terraced paddy fields were developed from the end of the medieval time to the Edo era on mildly-sloped land due to a landslide, which has created a magnificent landscape. As previously discussed, how the current agricultural landscape was formed can be of interest to tourists, and therefore this agricultural history can be considered as a tourism resource. In addition, specialty products and places such as following are vital resources: wine produced by Iwanohara Vineyard, Kome to Sake no Nazo Kura (The Rice and Sake Warehouse of Wonder), Sakaguchi Memorial Hall, Japanese sake, and Yoshikawa Toji no Sato. Furthermore, traditional migratory labor practices that occurred in winter can also be made into a tourism resource. Heavy snow forced people to move temporarily in winter to find work, yet during their sojourns many people learned to make sake.

Figure 9 is a draft proposal to implement tourism development by considering the above mentioned urban and rural tourism resources and collaborating with the existing tourism resources. One (1) is the route comparing urban spaces in the ancient and medieval times, the Warring states period, and the Edo era. Two 


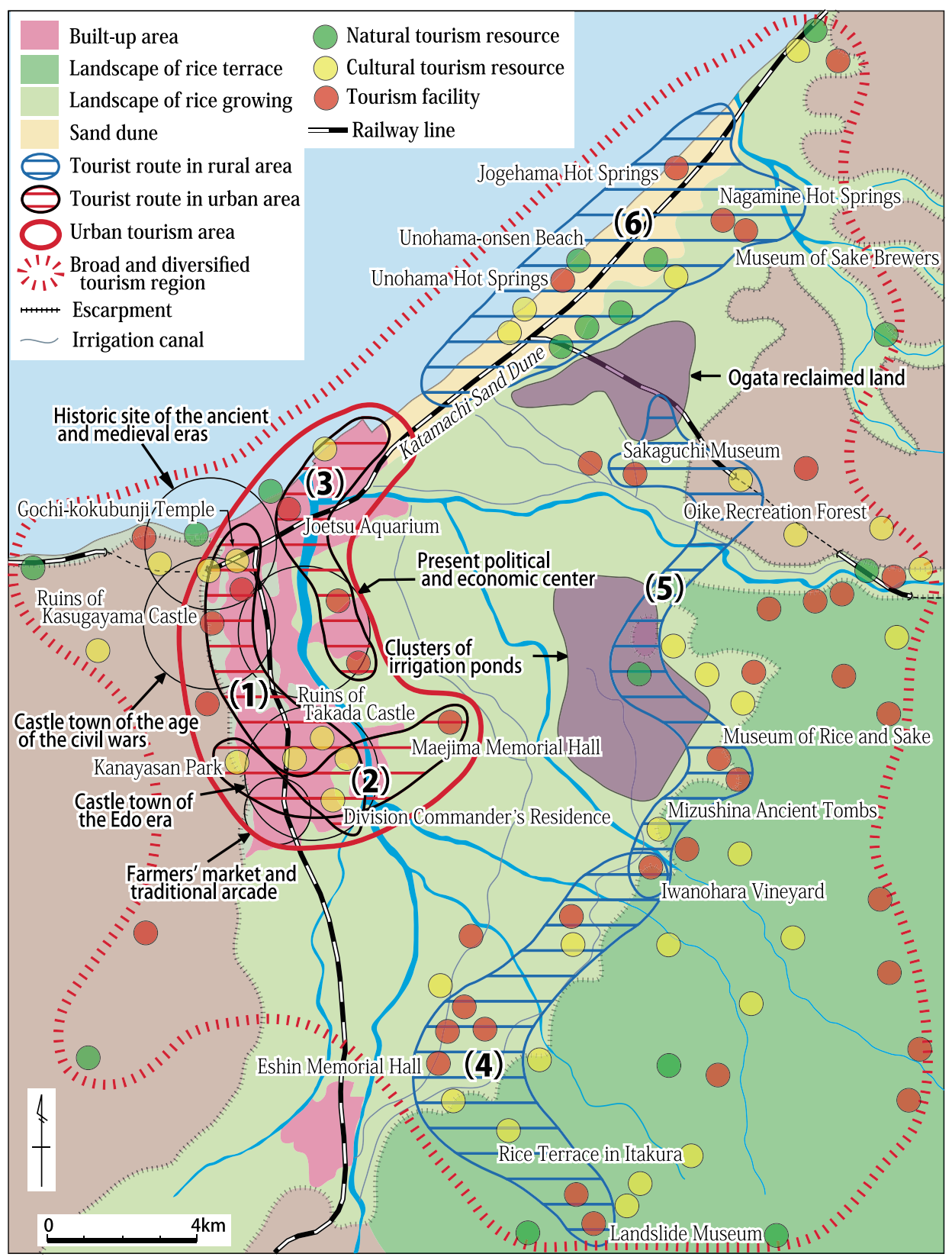

(1) The route comprising urban spaces in ancient and medieval time, the Warring states period,and the Edo era.

(2) The route following urban spaces after the Meiji era.

(3) The route exploring the new urban route, including the present administrative district, shopping centers, and Naoetsu port

(4) The route to understand landslide terrain, see terraced paddy fields, visit Uwae irrigation canal on the plain area where water shortage occurred, and understand the current paddy farming village landscapes.

(5) The route to tour districts that are experiencing water shortages in downstream area of Uwae irrigation canal and visit Sake breweries and museums.

(6) The route to enjoy hot springs and to understand dune development.

Figure 9. Possibility of tourism development owing to the commodification of rural and urban spaces in the Joetsu Region.

Data sources: Statistics of Joetsu city and interviews.

(2) is the route following urban spaces after the Meiji era. Three (3) is the route exploring the new urban route, including the present administrative district, shopping centers, and Naoetsu port. Four (4) is the route to understand landslide terrain, see terraced paddy fields on the landslide, visit Uwae irrigation canal developed on the plain area where water shortages occurred due to terraced paddy field development in the mountain ringed region, and understand the current paddy farming village landscapes. Incorporating farming experience in mountain ringed regions such as old Yasuzuka Town and old Uragawara Village on Takada plain will make tourism more diversified. Five (5) is the route to tour districts that are experiencing water shortage in downstream areas 
of Uwae canal and visit Sake breweries and museums. Finally, six (6) is the route to enjoy hot springs and to understand dune development.

\section{Case Study of the Kurobe Alluvial Fan in Toyama Prefecture}

\section{Tourism trend}

The Kurobe alluvial fan and its surrounding area have few special tourism resources except Kurobe Gorge and Unazuki hot springs in the upper course of the Kurobe River. Thus, the Kurobe alluvial fan has not attracted many tourists. In 2008 the number of the tourists visiting Kurobe city was 2,630,000, 530,000 in Nyuzen town, and 310,000 in Asahi town with a total of 3,470,000. Looking at the trend in the number of tourists from 1991 to 2008, in old Unazuki town the numbers have been consistently decreasing with the largest number of tourists in 1991 when there were, for example, 1,440,000 in 1991 and $1,140,000$ in 2005 . The number of tourists in Unazuki hot springs, a center of tourism, has decreased by two thirds from 1991 as a peak year, which has affected the number of tourists to old Unazuki town. On the other hand, although the number of tourists was only 329,000 in old Kurobe city in 1991, it increased to over 500,000 in the late 1990s, and it continued to increase such that there were 810,000 tourists in 2004. The development and preparation of Kurobe City International Culture Hall, "Colare" and Kurobe City Comprehensive Park began in the middle of the 1990s, and the actual use started around the year 2000, which contributed the above-mentioned increase. In 2005, the number increased to 1,050,000, which resulted from the opening of the fishing station, "Ikuji". In Nyuzen town although the average number of tourists until 2000 was 150,000, it increased to 790,000 in 2002 owing to the expansion and improvement of the town's community center "Cosomo Hall" and the newly established Sawasugi Shizen Kan (Museum of Natural Cedar Forest) and a facility that uses deep sea water. However, the number of tourists has gradually decreased. In Asahi town, although the number of tourists increased due to the construction of various cultural and tourism facilities around 2000, recently numbers have decreased remarkably, including a sharp decrease of sea-goers.

\section{Tourism resources}

\section{Natural tourism resource}

In the following analysis, tourism resources on the Kurobe alluvial fan and its surrounding areas are examined by dividing them into natural and cultural tourism resources, and tourism facilities, just as they are analyzed in the Joetsu region. As for the natural tourism resource, Kurobe Gorge, first mentioned, it is a gorge formed by the Kurobe River, which originates in Mt. Washibadake in the Northern Alps, and the deepest section is $1500 \mathrm{~m}$. The Kurobe Gorge Railway runs $20.1 \mathrm{~km}$ from Unazuki to Keyakidaira, and one can see a magnificent view of the gorge from the train window. Approximately, 130 ha of cedar forests used to occupy the area of spring-fed water on the Kurobe alluvial fan. However, it has been reclaimed into rice paddies by the field improvement project since the 1960s, and only one cedar forest of 2.7 ha remains at present. The sand of Ishidahama bathing beach is protected by the breakwater in Ishida fishing harbor and Ishida fish arena, and it is crowded with beach-goers during the summer holidays. Among the Miyazaki and Sakai beaches in Asahi town is a rare gravel beach in Japan called jade beach since raw jade stones can be found there. It is also famous as a bathing beach. Asahi town is a starting point for a climb to Mt. Asahidake (2418 m) and Mt. Hakubadake (2932 m) in the northern Alps.

\section{Cultural tourism resource}

The ruin of Fudodo in Asahi town is a place of restored pit-houses from the middle of Jomon era (B.C. 3000), and the remains of a huge house that is four or five times larger than an ordinary house is noticeable. Akoyano Tomb is the oldest in Toyama prefecture, and the Akoyano family is said to have been the one of the most powerful families around the 6th century. Joubenoma is considered as the ruin of the administration office of manors in the early 9th century. Shiroyama Park was the home base of Taro Miyazaki, who is from a powerful family in the late 12th century, and Shiroyama is the oldest castle hill in Toyama prefecture. Miyanoyama Sports Park is a comprehensive athletic park built mainly on the land where soils were taken by hydraulic power of the Warp Soil Dressing Project, and the Kurobe alluvial fan is seen from there. Kurobe City Comprehensive Park consists of several facilities such as a swimming pool, gymnasium, museum, playground, and a waterway for nature observation.

\section{Tourism facility}

There are many tourism facilities on the Kurobe alluvial fan and its surrounding areas. Unazuki hot springs is the most significant. It is the largest in Toyama prefecture with 15 hotels and guest houses accommodating 3500 tourists. Unazauki Ski area and Unazuki International 
Hall with large and small halls and a convention hall are near the hot springs. Unazuki Beer Museum is located on the plain, which is $6.5 \mathrm{~km}$ away from the hot springs. Tourists can taste beer as well as learn about the beer production process. There are historical materials on the Kurobe River and old Unazuki town displayed in the Unazuki Yugaku Museum nearby, and visitors can walk over the restoration of Aimoto drawbridge of the Edo era. Old Kurobe city also has many facilities. In addition to two hot springs in Ikuji, Yoshida Science Museum has a planetarium and an exquisite view of the upper section of the Kurobe River, and the Northern Alps can be seen in 3D multi vision. The major facility of Kurobe City International Culture Hall is a concert hall with 886 seats, and there is also a multifunction hall, Noh-stage, creation room, study room, and a tea room. A fishing station, "Ikuji", is a direct fish market of Kurobe city fisheries cooperative, and a restaurant is attached to the market.

Nyuzen town also has a large number of facilities. Nyuzen Town Community Center consists of a town community center (commonly called Cosmo Hall) and a library. Uruoi Hall consists of an event hall accommodating 500 people, a sound proof multi functional room, and a media room with personal computers installed. Nizayama Art Forest and Electric Power Plant Museum were remodeled from an electric power plant built with red bricks in 1925. There is a facility that extracts and uses sea water that is rich in minerals and salt from $384 \mathrm{~m}$ deep, and it has displays on deep water extraction and sells related products. Funami Ruin Castle Museum was built at the site, modeled after the ruin of a castle hill in the medieval age and was designed for tourism. The Kurobe alluvial fan can be viewed from its top floor.

In Asahi town there are many facilities allocated around the previously mentioned ruin of Fudodo: a water mill; a restored merchant town house of the Edo era; a historical park; Ippuku Museum displaying old art work of China, Korea, India, and Japan; restaurants; and Nanairo KAN (hall) where one can experience pottery and glass making. Maibun KAN is also nearby, and it displays Jomon pottery, stone tools, and comma-shaped gems unearthed in Asahi town. Sunreana is a gymnasium which has 10 badminton courts and is used for concerts and plays since it has a stage. Furusato Museum shows works by artists from or related to local areas. In addition, Rakuchino is a bathing facility, utilizing heat produced by waste disposal in the cleaning center with a swimming pool, a spa, and a fitness room. Ogawa Motoyu hot springs is an old hot spring discovered in the early Edo era.

\section{Distribution of tourism resources}

Figure 10 shows the distribution of tourists by major tourism resources in 2008. According to this, the tram of the Kurobe Gorge Railway has the most tourists, 500,000, followed by Kurobe City Comprehensive Park, 440,000, Unazuki hot springs, 386,000, Fishing Station "Ikuji", 227,000, Nyuzen Town Community Center and Cosmo Hall, 226,000, Miyanoyama Spots Park, 196,000, and Kurobe City International Culture Hall, 148,000. Every tourist resource in Asahi town attracted only a small number of tourists, and the place with the largest number, 85,000, was Miyazaki and Sakai beach, followed by Ogawa Motoyu hot springs, 61,000, and Nanairo KAN, 33,000. The number of tourists at the ruin of Fudodo, which Asahi town is proud of and is an officially-designated historical site, was only 2,986. Cedar Forest Museum, which was designated as a national natural treasure in Nyuzen town, had 22,000 tourists.

Except for a tram of the Kurobe Gorge Railway, Unazuki hot springs, and Fishing Station "Ikuji", most tourism resources are public facilities that local residents use for cultural and educational activities, sports, and social interaction, and were not originally used for tourist purposes. As pointed out, many of the tourist resources on the Kurobe alluvial fan are small-scale and not well known. They tend to be scattered, in particular, on the west side of the Kurobe River. In addition, although some tourist resources are significant in academic terms, they are not developed enough nor well advertised, and as a result, there are few tourism resources attracting tourists from other regions. The tourism amenities that tourists visit are not stimulating except for some in Kurobe city.

\section{Discovery of new tourism resources owing to the commodification of rural spaces}

Tourism resources can be defined when the commodification of rural spaces is considered in terms of educational experience-based tourism on the Kurobe alluvial fan. Mizushima (1993) advocates that the existence of the Kurobe Alluvial Fan Museum gives social, economic, historic and cultural value to the rich natural characteristics, which are preserved for the enlightenment and education of the future generations. These tourism resources were amended and will be introduced here.

As natural tourism resources, daily natural environments such as old alluvial fans, terraced escarpments, dispersed rural settlements, and characteristics of the Kurobe River which local residents usually neglect, may be extremely precious tourism resources to outsiders: shore erosion, submarine buried 


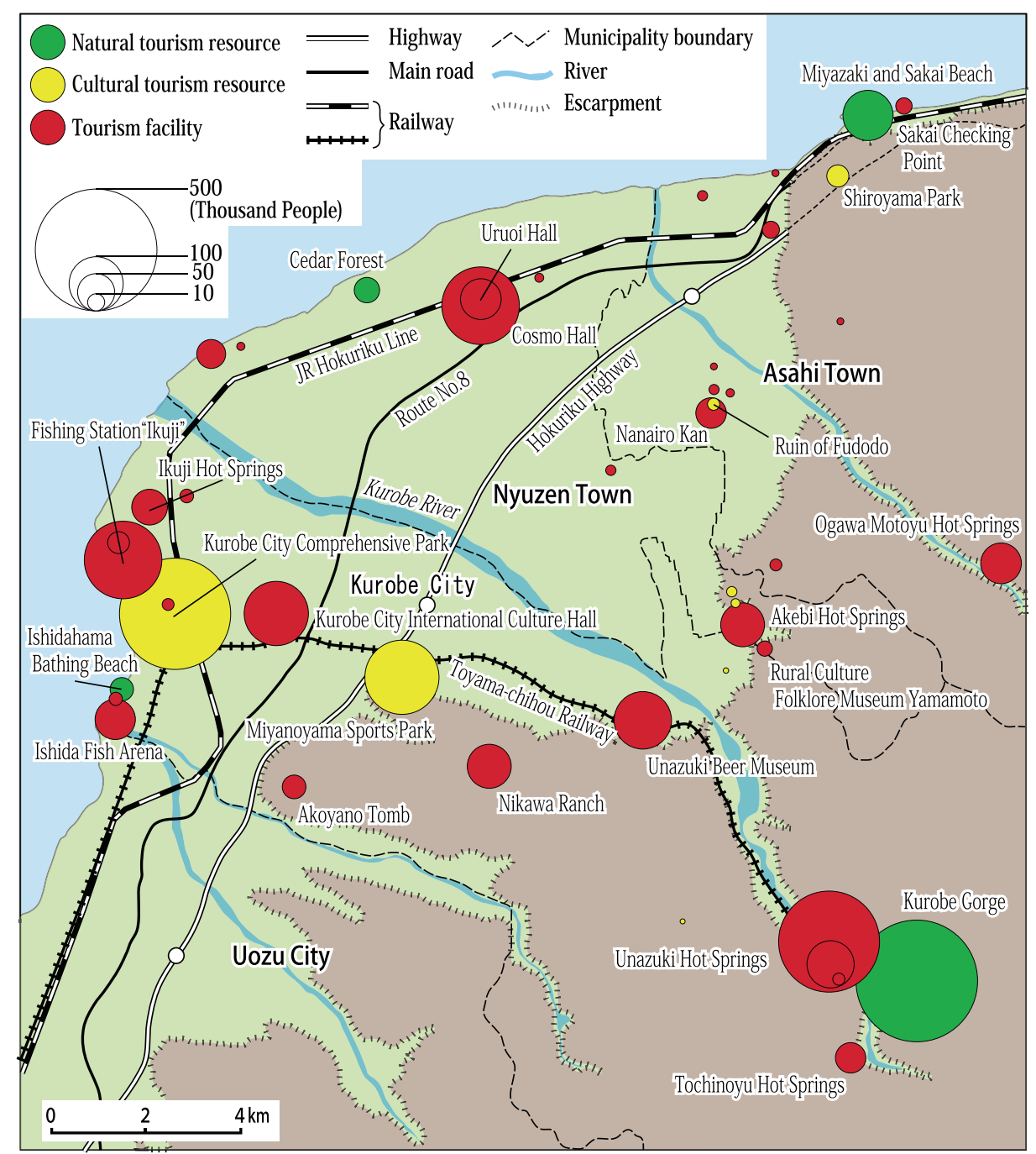

Figure 10. Distribution of tourism resources and tourists on the Kurobe Alluvial Fan. Data sources: Tourist statistics of Toyama prefecture, tourist brochures and interviews.

forests, coastal dune, deltas, cedar swamps, land features of the alluvial fan, Maezawa Terrace, Funamino Terrace, Junikanno Plateau, and Tanayama Plateau. For example, the magnificent land features shown on $1 / 50,000$ topographic maps are actually observable from a tower in the Cedar Forest Museum, from Miyanoyama Sports Park, or from the Funami Ruin Castle Museum, and the land features and formation mechanisms of the alluvial fan are easily comprehended from these vantage points.

Structures built on these natural bases can also be culture tourism resources. Open levees and old dikes for the Kurobe River improvement, various types of spur dikes, and Mizu Shrine (a shrine to honor a water God) are exemplified. Furthermore, Aimoto Dam, the East and West Gouguchi canals, and the main, branch, and fringe irrigation canals should also be pointed out(Tabayashi 1990). A great number of parks and green spaces established on the dry riverbed of the Kurobe River, landscapes of farm product cultivation, Koshihikari brand rice, Kurobe watermelons, tulip bulbs, and Japanese sake can also be tourism resources. The following must be focused: landscapes of an old post station on Hokuriku Road, landscapes of other existing towns, historic sites that have not been considered tourism resources, and new facilities such as a wind power plant of Nyuzen Town Purification Center.

Actually learning and experiencing activities are necessary in order to utilize the resources mentioned above: cultivating rice and watermelons, running a dairy operation, fisheries industry and fish products including sunning on a beach, drying and salting fish and seaweeds, and making fish cake. Also, large industry facilities such as YKK can involve both a YKK plant visit and a tour of its surrounding areas, town walking including such places as Mikkaichi, Tomari, and Sakai. Many artesian springs near the coastal area may attract many tourists (Figure 11). In addition, the observation and study of cultural and historical phenomena as well as natural, 


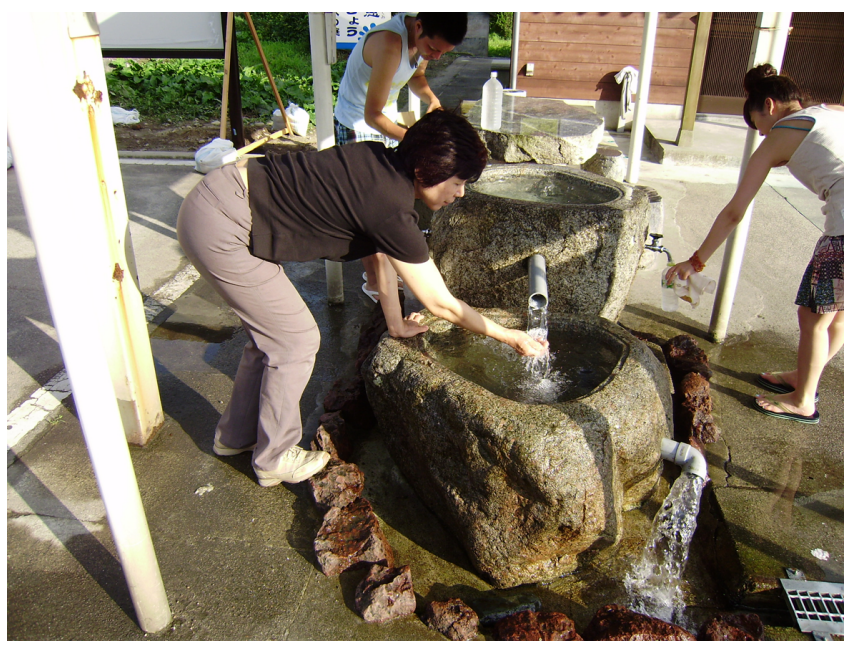

Figure 11. Artesian spring on the Kurobe Alluvial Fan. Taken by the author, August 2009.

economic and social phenomena should be considered. By relating new tourism resources discovered through the commodification of the above mentioned rural spaces to the existing tourism resources there will be the possibility to realize more fulfilling tourism along model tourist routes shown in tourism brochures in each municipality due to their linear and dimensional expansions (Figure 12).

\section{Field museum and regional development}

Tourism on the Kurobe alluvial fan will be more fulfilling with the commodification of rural spaces; however, there are limitations to implement regional development programs through tourism in this region. Residents need to be interested in their local area and research local nature, landscapes, lifestyle, and culture, to recognize the value of their existence and to be proud of them; this must be related to regional construction. Thus, lifelong learning and education should be promoted. As a result of firmly adopted local people's activities, it can be strongly anticipated that the number of tourists from other regions and prefectures will increase.

In the Greater Niikawa, Toyama prefecture, a "Water Museum" focusing on the Kurobe alluvial fan has been envisaged for many years. This concept has been promoted by the Water Museum Concept Promotion Council (tentative name) which consists of Uozu and Kurobe cities, Nyuzen and Asahi towns, and Toyama prefecture. The Water Museum Concept Promotion Department established in the Greater Niikawa Administration Association in 2001 creates museum activities (Mizu Hakubutsukan Kihon Koso Sakutei Iinkai 2002). Various materials related to water in the Kurobe River basin are considered as Water Museum displays and local visits and experience are available, which promotes the protection and maintenance of water, water environment and the sustainability of the entire regional society. Regional curators who will play main roles in the field activities are trained so that they can conduct field tours to experience the water environment. The museum activities have been coordinated with regional activity groups and schools.

A similar approach to this is eco-museum activity, which can be seen in various regions. The heritages and memories of a given place are targeted, and local residents are responsible for a museum activity (Arai 1995; Oohara 1999). This activity not only preserves the heritage but also functions to create the future region. In terms of ecomuseum activity, Asahi town, Yamagata prefecture, has a triplex structure of autonomous, district, and central community centers that support lifelong education and regional construction through eco-museum activities (Komatsu 1999; Hoshiyama 2005). Such a system of community centers has been prepared for many years on the Kurobe alluvial fan, and it has played a major role to facilitate the promotion of regional culture and communication (Tabayashi 1988). Meanwhile, an autonomous community center in a village, a district community center in the area of each old municipality established in the Meiji era, and a central community center in all municipalities were set up, and residents can utilize three scales of facilities with different functions. The utilization of such a community center system is considered as helping to promote the adoption of local field museum activities.

Regional development owing to tourism is limited on the Kurobe alluvial fan and its surrounding areas. Thus, the commodification of rural spaces with local residents in mind should be promoted, and residents should consider regional construction through the study and understanding of regional resources and heritages when the rural space in which they exist is commodified. Significant growth to tourism is possible if such rural spaces are commodified.

\section{Possibility of Regional Development owing to the Commodification of Rural Spaces}

This paper has examined the possibility of expanding rural tourism in the Nasu, the Joetsu, and the Kurobe river regions (Table 1). Many tourists visit the Nasu region from the Tokyo Metropolitan area since they can use the bullet train line and the Tohoku Expressway. The number of tourists in 2006 was $8,280,000$. This 


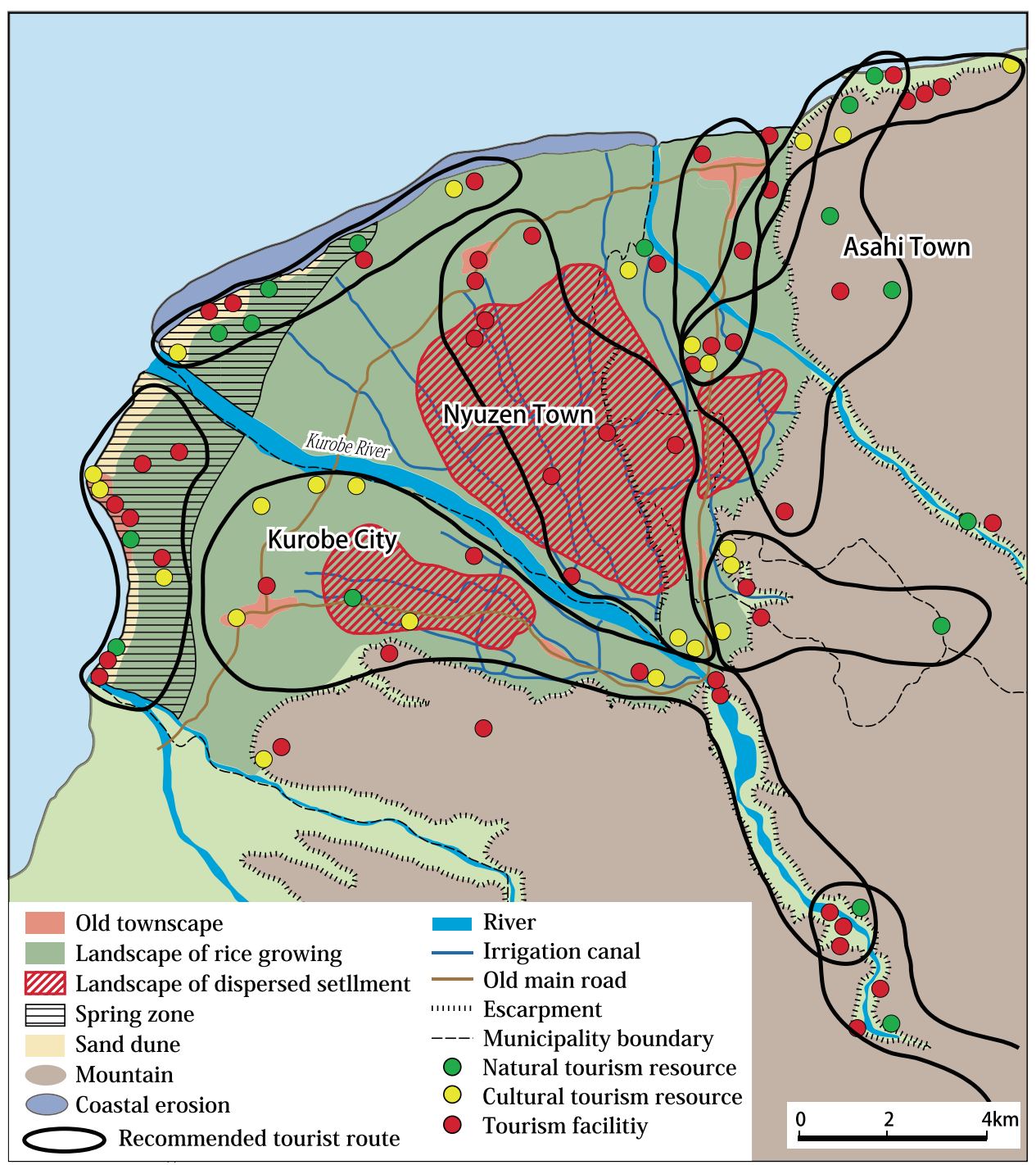

Figure 12. New tourism resources owing to the commodification of rural spaces and recommended tourist routes on the Kurobe alluvial fan.

Data sources: Mizushima 1993, tourist brochures and interviews.

region consists of well known Shiobara hot springs and Nasu highland, which was established as a tourist site with various recreation functions, including hot springs, mountain climbing, hiking, cottage staying, and vast areas of farming, which have been developed since the Meiji era. While tourist sites have stagnated after the collapse of the economic bubble, the region's economy has been stimulated in order to create a broad spectrum of tourism opportunities owing to the commodification of rural spaces, in addition to enhancing hot spring and tourism facilities in the Nasu region.

The Joetsu region is far from Tokyo. It has been the site of a castle town since medieval times and flourished as a center of public administration and commerce. A vast rice cropping area surrounds it. Regional development has been stimulated by the further enhancement of tourism facilities, the improvement of large commerce facilities, and a strong tourism policy in Joetsu city. The
Joetsu region has a vision to break through the current stagnant situation by commodifying rural and urban spaces. That is, this region has been developing owing to tourism resources which other regions do not have, such as historic sites related to famous leader Kenshin Uesugi.

The Kurobe alluvial fan is far from the all large metropolitan areas; Tokyo, Osaka, and Nagoya. Although it has the nationally known tourism resource, Kurobe Gorge, the region's character is defined mainly as a rural space. The Kurobe alluvial fan is different from other two regions, and tourism sites are not established. The commodification of rural spaces can develop a certain degree of tourism; however, there are limitations. The region should focus on attracting tourists from other regions as a result of regional development by conducting lifelong and social education through the commodification of rural spaces.

The differences among three regions are due to the 
Table 1. Comparison of three study regions

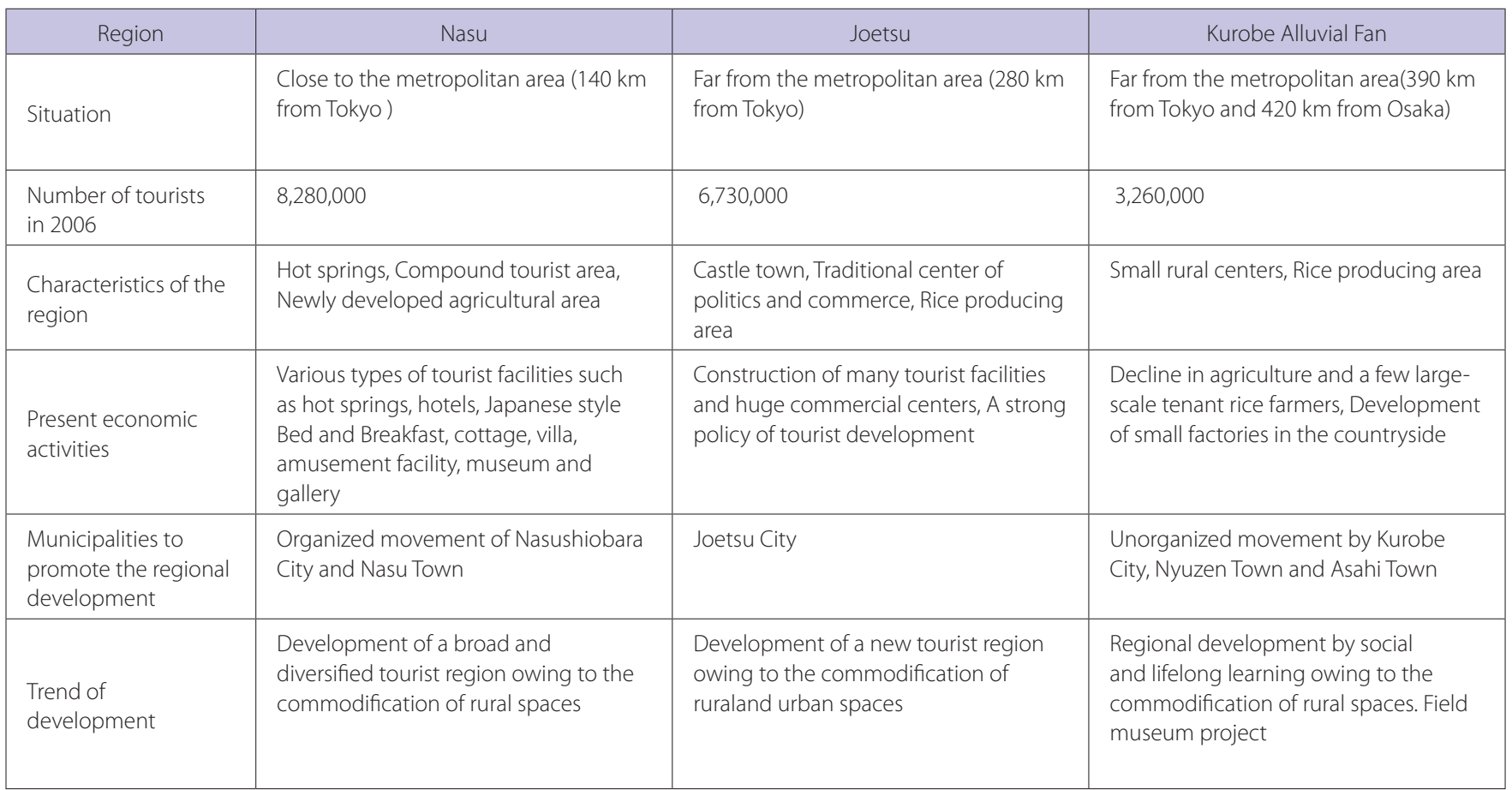

distance from the large metropolitan areas, tourism markets and the scale of the current tourism performance and potential in each region. The Nasu region has the most advantages followed by the Joetsu region, and the Kurobe alluvial fan has the least. In addition, organizations that strongly promote tourism are included in one governmental body, and Joetsu city has vigorously implemented tourism development in the Joetsu region. Nasushiobara city and Nasu town have collaborated to stimulate tourism development in the Nasu region. Unlike these two regions, the Kurobe alluvial fan has three governmental bodies, and tourism promotion is not well integrated.

\section{Conclusion}

Instead of the farm production function of Japanese rural regions, the tendency to focus on other functions including leisure, relaxation, culture, education, and environmental conservation has been emphasized. On the other hand, as one of the current tourism activity features, there is a strong tendency to utilize the following: the terraced paddy field landscape, satoyama (the border area between the foot of a mountain and arable flat land), traditional cityscape, landscapes of agricultural mountain villages, farm products, food culture, and lifestyle. In particular, the use of agriculture and rural resources in tourism and eco-tourism has been emphasized. Thus, tourism activities have been taking place in the context of the commodification of rural spaces.

In this paper, the possibility of regional development through rural commodification has been studied by comparing the Nasu region, the Joetsu region, and the Kurobe alluvial fan. In the current tourism areas such as Shiobara hot springs and Nasu highland, which have been developed based on hot spring tourism, recently tourism development has been advanced by the commodification of rural spaces such as improvement of hiking courses, providing farm experiences, promoting farm product markets, and establishing restaurants serving locally produced food. Furthermore, the use of the following as tourism resources has been promoted: farm landscapes of the vast Nasu alluvial fan located between Shiobara hot springs and Nasu highland, its pioneer history, and the achievement of Rural Space Museum Project that was recently completed by the Ministry of Agriculture, Forestry and Fisheries of Japan. Consequently, individual tourism areas including Itamurao hot springs will be consolidated, and a broad-based tourism region will be formed, with a high probability that the region will contribute to the development of the entire Nasu region.

The current issues in the Joetsu region are as follows: how to mutually connect the many small-scale scattered tourism resources, what new tourism resources should be promoted, and how educational and experiential tourisms should be incorporated. Thus, the commodification of rural and urban spaces is essential. In the built-up area of Takada, urban planning of a castle town in the early 
Edo era established the current urban structure. In this region, by commodifying the daily life spaces such as regional structure of the castle town, the scenery of broad eaves overhanging sidewalks in the snowy urban core, and morning markets, tourism can be diversified. Similarly, future tourism development is expected by expanding current tourism through the commodification of rural spaces such as irrigation canals, holding ponds, dunes, and terraced paddy fields as cultural assets, and using rural village landscapes and various farm products including rice and Japanese sake as tourism resources.

Compared to the Nasu region and the Joetsu region, the Kurobe alluvial fan is a rural area with few remarkable tourism resources. Tourism development thorough the commodification of rural spaces is limited here. Residents should evaluate familiar production activities, industry, landscape, lifestyle, and annual events and consider the direction for regional development themselves through study and experience. The result will attract tourists from other regions and contribute to tourism development.

The most significant factors of the differences among the three regions are the scale of the current and potential tourism resources and the difference in distances from major metropolitan centers. In order to realize regional development through the commodification of rural spaces in any region, transportation to connect a broad based region needs to be secured, while preparation and improvement of core centralized facilities, and the creation of organizations to manage the entire region are necessary. In addition, establishing human resources promoting regional development and the existence of active regional residents are critical.

\section{Acknowledgements}

The local investigation would not have been possible without support of many people. Many thanks to the office staffs of the industry and tourism divisions of the Nasushiobara city, Nasu town, Joetsu city, Kurobe city, Nyuzen town and Asahi town offices. I am grateful to Dr. Tom Waldichuk at Thompson Rivers University for his review and insightful comments. Also I wish to thank Professor Kazuo Mizushima at Nihon University and the graduate students of the University of Tsukuba: Mr. Yasuhiko Tanno, Takafumi Yokoyama, Kunimitsu Yoshida, Takayuki Oishi, Kota Ishida, Mariko Ito and Kana Umeda. The main outline of this paper was presented at the Special Meeting of the Human Geographical Society of Japan (Kurobe Alluvial Fan Research Center)in June 2009. This study was partly supported by a Grant-in-
Aid for Scientific Research (A) 2007-2009, "Human Geographical Study on the Commodification of Rural Spaces in Japan" (Representative Akira Tabayashi, Proposed Number: 19202027).

\section{References}

Adachi, Y., Takayama, M. and Sakagawa, J. 2006. Nasu senjochi to sono shuhen chiiki niokeru koiki kanko eria keisei no kanosei (Possibility of a broad based tourism area on the Nasu alluvial fan and its vicinity). Shizen to Kurashi (Nature and lifestlye) 13: 1-24. (J)

Akitsu, M. 2007. Karuchuraru taan suru inaka: Ima doki nouson shakai kenkyu gaido (Countryside under cultural turn: An introduction to the present study on rural societies). In Seibutsu shigen mondai to sekai (Problems of biological resources and the world), ed. K. Noda, 147-177. Kyoto: Kyoto Daigaku Gakujutsu Shuppankai. (J)

Arai, J. ed. 1995. Eco-museum nyumon (Introduction to ecomuseum). Tokyo: Makino Suppan. (J)

Butler, R. 1998. Rural recreation and tourism. In The geography of rural change, ed. B. Ilbery, 211-232. London: Longman.

Cloke, P. 1992. The countryside: Development, conservation and an increasingly marketable commodity. In Policy and change in Thatcher's Britain. ed. P. Cloke, 269-295. London: Pergamon Press.

Cloke, P. 1993. The countryside as commodity: New rural spaces for leisure. In Leisure and the environment: Essays in honour of Professor J. A. Patmore, ed. S. Glyptis, 53-67. London: Belhaven Press.

Dahms, F. A. 1996. The graying of south Georgian Bay. The Canadian Geographer 40: 148-163.

Hoshiyama, Y. ed. 2005. Shizen tono kyousei to machi zukuri (Town planning by the coexsistence of nature and men). Tokyo: Hokuju Shuppan. (J)

Ilbery, B. and Bowler, I. 1998. From agricultural productivism to post-productivism. In The geography of rural change, ed. B. Ilbery, 57-84. Harlow: Longman.

Joetsu City 2001. Joetsu Shi dai 2ji kanko shinko 5kanen keikaku (Five year project of the second tourism promotion project in Joetsu City). Joetsu: Joestsu City. (J)

Joetsu City 2006. Joetsu Shi dai 3ji kanko shinko 5kanen keikaku (Five year project of the third tourism promotion project in Joetsu City). Joetsu: Joetsu City. (J)

Komatsu, K. ed. 1999. Eco-museum: 21seiki no chiiki okoshi (Ecomusuem: Regional planning in the 21th century). Tokyo: Ieno Hikari Kyokai. (J)

Kubiki Sonshi Hensan Iinkai ed. 1988. Kubiki sonshi (History of Kubiki village). Kubiki: Kubiki Village. (J)

Minamigaoka Bokujo ed. 1998. Minamigaoka Bokujo 50nen no ayumi (50 Year development of Minamigaoka Ranch). Nasu: Minamaigaoka Bokujo. (J)

Mizu Hakubutsukan Kihon Koso Sakutei Iinkai 2002. Mizu hakubutsukan kihon koso (Basic concept of water museum). Uozu: Mizu Hakubutsukan Kihon Koso Sakutei Iinkai. (J)

Mizushima, K. 1993. Kurobegawa senjochi hakubutsukan no 
kangaekata (The idea of the Kurobe alluvial fan museum). Kurobe Regional Studies 18: 12-19.

Nasu Machi Kyoiku Iinkai ed. 2005. Nasu onsenshi (History of Nasu hot springs). Nasu: Nasu Town. (J)

Nasu Sosui Hyakunenshi Hensan Iinkai ed. 1985. Nasu sosui hyakunenshi (100 year history of Nasu irrigation canal). Kuroiso: Nasu Sosui Tochikairyoku. (J)

Nihon Chishi Kenkyujo, Aono, H. and Birukawa, S. ed. 1968. Nihon chisi dai 5kan, Kanto, Ibaraki-ken, Tochigi-ken (Geography of Japan: Vol. 5 Kanto, Ibaraki Prefecture and Tochigi Prefecture). Tokyo: Ninomiya Shoten. (J)

Nishi Nasuno Choshi Hensan Iinkai ed. 2000. Nishinasuno Machi no kaitakushi (Pioneering history of Nishinasuno Town). Nishinasuno: Nishinasuno Town.

Oohara, K.1999. Eco-museum eno tabi (Journey to eco-museum). Tokyo: Kashima Suppankai. (J)

Perkins, H.C. 2006. Commodification:re-resourcing rural areas. In Handbook of rural studies, ed. P. Cloke, T. Marsden and P. H. Mooney, 243-257, London: SAGE Publications.

Shiobara Choshi Hensan Iinkai ed. 1980. Shiobara choshi (Geography and history of Shiobara Town). Shiobara: Shiobara Town. (J)

Tabayashi, A. 1988. Communication and community halls in rural regions of the Kurobe alluvial fan. Tsukuba Studies in Human Geography 12: 87-112. (JE)

Tabayashi, A. 1990. Nogyosuiri no kukankozo (Spatial structure of irrigation systems). Tokyo: Taimeido. (J)
Tabayashi, A. 1991. Senjochi noson no henyo to chiiki kouzo (Changing rural area of the Kurobe alluvial fan and its regional structure). Tokyo: Kokonshoin. (J)

Tabayashi, A. 2007. Structural change of agriculture and successor of farming in Japan. Annals of the Japanese Association of Economic Geographers 53: 3-25. (JE)

Tabayashi, A., Ishida, K., Ito, M. and Umehara, K. 2008. Development of tourist industry based on regional resources in the Takada plain and its vicinity, Niigata Prefecture. Studies in Human Geography 32: 69-93. (JE)

Tabayashi, A., Tanno, Y., Yokoyama, T., and Yoshida, K. 2008. Proposed development of tourist industries based on the commodification of rural spaces. Geographical Space 1: 83113. (JE)

Tachikawa, M. 2005. Post-productivist transition of rural Japan and transformation of its social representation. Annual Bulletin of Rural Studies 41: 7-40. (JE)

Takahashi, M. 1999. Post-productivist countryside, commodification and rural planning: Notes on social construction of rurality-II. Studies in Information and Sciences 9: 79-97. (JE)

Woods, M. 2005. Rural geography. London: SAGE Publications.

( $\mathrm{J})$ : written in Japanese

(JE): written in Japanese with English abstract 